IZA DP No. 9132

Cognitive, Non-Cognitive Skills and Gender Wage Gaps:

Evidence from Linked Employer-Employee Data in Bangladesh

Christophe J. Nordman

Leopold R. Sarr

Smriti Sharma

June 2015 


\title{
Cognitive, Non-Cognitive Skills and Gender Wage Gaps: Evidence from Linked Employer-Employee Data in Bangladesh
}

\author{
Christophe J. Nordman \\ DIAL (IRD \& University Paris-Dauphine) and IZA \\ Leopold R. Sarr \\ World Bank \\ Smriti Sharma \\ UNU-WIDER
}

Discussion Paper No. 9132

June 2015

IZA

P.O. Box 7240

53072 Bonn

Germany

Phone: +49-228-3894-0

Fax: +49-228-3894-180

E-mail: iza@iza.org

Any opinions expressed here are those of the author(s) and not those of IZA. Research published in this series may include views on policy, but the institute itself takes no institutional policy positions. The IZA research network is committed to the IZA Guiding Principles of Research Integrity.

The Institute for the Study of Labor (IZA) in Bonn is a local and virtual international research center and a place of communication between science, politics and business. IZA is an independent nonprofit organization supported by Deutsche Post Foundation. The center is associated with the University of Bonn and offers a stimulating research environment through its international network, workshops and conferences, data service, project support, research visits and doctoral program. IZA engages in (i) original and internationally competitive research in all fields of labor economics, (ii) development of policy concepts, and (iii) dissemination of research results and concepts to the interested public.

IZA Discussion Papers often represent preliminary work and are circulated to encourage discussion. Citation of such a paper should account for its provisional character. A revised version may be available directly from the author. 


\section{ABSTRACT \\ Cognitive, Non-Cognitive Skills and Gender Wage Gaps: Evidence from Linked Employer-Employee Data in Bangladesh ${ }^{*}$}

We use a first-hand linked employer-employee dataset representing the formal sector of Bangladesh to explain gender wage gaps by the inclusion of measures of cognitive skills and personality traits. Our results show that while cognitive skills are important in determining mean wages, personality traits have little explanatory power. However, quantile regressions indicate that personality traits do matter in certain parts of the conditional wage distribution, especially for wages of females. Cognitive skills as measured by reading and numeracy also confer different benefits across the wage distribution to females and males respectively. Quantile decompositions indicate that these skills and traits reduce the unexplained gender gap, mainly in the upper parts of the wage distribution. Finally, results suggest that employers place greater consideration on observables such as academic background and prior work experience, and may also make assumptions about the existence of sex-specific skills of their workers, which could then widen the within-firm gender wage gap.

JEL Classification: J16, J24, J31, J71, C21, O12

Keywords: gender wage gap, cognitive skills, personality traits, matched worker-firm data, quantile decompositions, Bangladesh

Corresponding author:

Christophe J. Nordman

IRD, DIAL

4 rue d'Enghien

75010 Paris

France

E-mail: nordman@dial.prd.fr

\footnotetext{
* This paper has benefited from comments received from Paul Glewwe, Prakarsh Singh, Saurabh Singhal and participants at IZA/OECD/World Bank Workshop on Cognitive and Non-Cognitive Skills and Economic Development 2014, $10^{\text {th }}$ Annual Conference on Economic Growth and Development, Indian Statistical Institute, Royal Economic Society Conference 2015, Midwest International Economic Development Conference 2015 and the $10^{\text {th }}$ IZA/World Bank Conference on Employment and Development. The usual disclaimer applies.
} 


\section{Introduction}

Non-cognitive skills or personality traits have recently received significant attention as determinants of labour market performance. In fact, these non-cognitive traits, referring to qualities such as motivation, leadership, self-esteem, social skills, etc., have in some cases been shown to be at least as important as cognitive skills for wages and employment prospects (e.g., Heckman et al., 2006; Lindqvist and Vestman, 2011)!1 Theoretically, personality traits can have both direct and indirect effects on productivity (Borghans et al., 2008). They can affect productivity directly by being considered as part of an individual's set of endowments, or serve as incentive-enhancing preferences (Bowles et al., 2001). Additionally, they can indirectly affect productivity, for instance, through effects on occupational choice (Cobb-Clark and Tan, 2011) and educational attainment (Heckman et al., 2011).

There is a growing body of literature that has explored gender differences in personality traits as potential alternative explanations of the gender wage gap $\mathrm{L}^{2}$ However, the existing evidence is based predominantly on developed economies with results indicating considerable variation in the contribution of these traits to the wage gaps. For instance, Mueller and Plug (2006) find that 3 percent of the gender wage gap in U.S. is explained by differences in personality traits (measured by the Big Five). On the other hand, Fortin (2008), on U.S. workers also reports that 8 percent of the gender wage gap is explained by differences in non-cognitive traits such as importance of money/work and importance of people/family. A similar magnitude has been documented for Russia (Semykina and Linz, 2007), while for Germany the effects are relatively minor (Braakmann, 2009). Using Australian data, Cobb-Clark and Tan (2011) find that men's and women's non-cognitive skills significantly influence sorting into occupations although the nature of this relationship varies across gender.

In this paper, our objective is to explain gender wage gaps in the formal sector of Bangladesh as a function of gender differences in cognitive skills and personality traits, over and above the standard variables included in Mincerian wage regressions. Gender disparities heavily characterize the Bangladeshi labour market. The increase in the proportion of females in the labour force, from 26 percent in 2002-03 to 36 percent in 2010 (Bangladesh Bureau of Statistics, 2011), has been largely on account of the rapidly

\footnotetext{
${ }^{1}$ Heckman et al. (2006) show that if an individual moves from the 25 th percentile to the 75 th percentile in the distribution of non-cognitive skills, wages at age 30 improve by about 10 percent for males, and by more than 30 percent for females. In comparison, a similar movement in the cognitive skill distribution leads to a 20 percent wage increase for males and to 30 percent increase for females.

${ }^{2}$ Further, a large experimental literature shows that men and women tend to differ in behavioural traits such as competitiveness (e.g., Niederle and Vesterlund, 2007), risk aversion (e.g., Croson and Gneezy, 2009) and willingness to negotiate (e.g., Babcock and Laschever, 2003), factors that can partly explain gender differences in outcomes such as job entry (Flory et al., 2015) and wages (Card et al., 2013).
} 
growing ready-made garment sector, where females constitute 80 percent of factory workers and approximately 15 percent of women aged 16-30 work in this sector (see Heath and Mobarak, 2015 and references therein). In terms of wages, Kapsos (2008) finds that women in the non-agricultural sector earn 21 percent less per hour than men while Ahmed and Maitra (2010) find that gender wage gaps are substantially higher in urban areas. While the literature on estimating gender wage gaps in developing and transition countries is fairly large (e.g., Appleton et al., 1999; Chi and Li, 2008; Nordman and Roubaud, 2009; Nordman et al., 2011), evidence documenting the influence of cognitive and noncognitive skills on gender wage gaps in a developing country context is scarce, primarily due to data limitations. With new data that allow us to identify these skills and traits for Bangladesh, to the best of our knowledge, our paper is among the first to contribute to this line of research examining the importance of cognitive and non-cognitive skills in explaining gender wage gaps in a developing country $\left.\right|^{3}$

Further, since looking at gender gaps at the means of men's and women's wages may only reveal part of the prevailing gender inequalities, we also conduct a distributional analysis of wage gaps. This allows us to analyze how cognitive skills and personality traits are valued at different points of the wage distribution. Quantile regression based decomposition techniques, that decompose wage gaps into explained and unexplained components at various points of the wage distribution, document mostly a "glass ceiling effect", i.e. the gender wage gap is increasing at the upper end of the wage distribution, for developed economies and some developing countries such as Morocco (Albrecht et al., 2003; Jellal et al., 2003; Nordman and Wolff, 2009a, 2009b). On the other hand, in Asian developing countries such as India, China, Vietnam and Bangladesh, larger wage gaps have been observed at the lower tails of the earnings distribution, i.e. the "sticky floor" phenomenon (Pham and Reilly, 2007; Khanna, 2012; Chi and Li, 2008; Ahmed and Maitra, 2011). Carrillo et al. (2014) based on their examination of gender wage gaps in twelve Latin American countries find that poorer and more unequal countries exhibit sticky floors whereas glass ceilings characterize richer and less unequal ones.

Since our data are collected at the enterprise level and contain information about both firms and employees, we make use of the linked employer-employee nature of the dataset. Household-level data typically do not allow one to control for firm characteristics that can often have important implications for wages and wage inequality (see Meng, 2004 and references therein). A priori, including firm-specific effects should alter the magnitude of the gender wage gap if (i), the wage gap is correlated, either negatively or positively, with the firms' observed and unobserved characteristics; (ii), the wage gap

\footnotetext{
${ }^{3} \mathrm{~A}$ few examples of developing country studies are Diaz et al. (2013) who find that Grit and some of the Big Five traits result in earning gains of 5-10 percent in urban Peru, and Glewwe et al. (2013) who find no evidence that non-cognitive skills matter for wage determination in rural China. But none of them examine the salience of these traits for gender wage gaps.
} 
between males and females is due to gender-based sorting of workers across firms that pay different wages. For instance, there is evidence of gender segregation across firms in the African manufacturing sector (Fafchamps et al., 2009) and in small firms in USA (Carrington and Troske, 1995). If there are high paying firms that hire more men than women and low paying firms hiring more women, then firms' characteristics will influence the gender differences in wages. Controlling for firm heterogeneity should then reduce the magnitude of the gender wage gap. With linked employer-employee data, we can include firm-specific effects to account for such firm-level influences on the gender wage gaps 45 We also use information on firm characteristics to examine correlates of within-firm gender wage gaps, relying on a two-step procedure including wage regressions and difference in firm fixed effects regressions.

Our results show that cognitive skills matter more than personality traits in determining mean wages. Where the personality traits do matter, it is mostly for wages of female employees, and only in certain parts of the wage distribution. Cognitive skills as measured by reading and numeracy also seem to confer benefits to women and men respectively, with returns varying across the wage distribution. The quantile decompositions indicate that cognitive skills and personality traits reduce the unexplained gender gap in the upper part of the wage distribution. Finally, the within-firm regressions suggest that employers may make assumptions about the existence of sex-specific skills of their workers, which could then widen the within-firm gender wage gap.

The paper is organized as follows: the next section discusses the methodology. Section 3 describes the data. Section 4 presents the descriptive statistics and results for mean and quantile decompositions, and within-firm gender wage gaps. Finally, Section 5 offers concluding comments.

\section{Methodology}

\subsection{Blinder-Oaxaca Decomposition Framework}

We first use the Blinder-Oaxaca method to decompose the mean wage gap between males and females into portions attributable to differences in the distribution of endowments (the explained component) and differences in returns to these endowments (the unexplained component) (Blinder, 1973; Oaxaca, 1973). This methodology involves estimating Mincerian wage equations separately for males and females. The decomposition is as follows:

$$
\bar{w}^{m}-\bar{w}^{f}=\left(\bar{X}^{m}-\bar{X}^{f}\right) \hat{\beta}^{m}+\bar{X}^{f}\left(\hat{\beta}^{m}-\hat{\beta}^{f}\right)
$$

\footnotetext{
${ }^{4} \mathrm{~A}$ caveat remains that employer-employee data are not representative of the population of interest at the country level, but to the extent that the firms' characteristics matter in the wage formation process, inclusion of firm-specific effects yields important advantages in studying wage gaps.
} 
where the left hand side of the equation is the difference in the mean log hourly wages of males and females. $\bar{X}^{m}$ and $\bar{X}^{f}$ are average characteristics for males and females respectively and $\hat{\beta}^{m}$ and $\hat{\beta}^{f}$ are the coefficient estimates from gender-specific OLS regressions. The first term on the right hand side represents the part of the wage differential due to differences in characteristics and the second term represents differences due to varying returns to the same characteristics.

In this paper, we also rely on the general decomposition proposed by Neumark (1988) in which the non-discriminatory wage structure is based on OLS estimates from a pooled regression (of both males and females) as follows:

$$
\bar{w}^{m}-\bar{w}^{f}=\left(\bar{X}^{m}-\bar{X}^{f}\right) \beta^{*}+\left[\left(\hat{\beta}^{m}-\beta^{*}\right) \bar{X}^{m}+\left(\beta^{*}-\hat{\beta}^{f}\right) \bar{X}^{f}\right]
$$

Neumark shows that $\beta^{*}$ can be estimated using the weighted average of the wage structures of males and females and advocates using the pooled sample. The first term is the gender wage gap attributable to differences in characteristics. The second and the third terms capture the difference between the actual and pooled returns for men and women, respectively.

\subsection{Quantile Decomposition Framework}

Generalising the traditional Blinder-Oaxaca decomposition that decomposes the wage gap at the mean, Machado and Mata (2005) proposed a decomposition method that involves estimating quantile regressions separately for males and females and then constructing a counterfactual using covariates of one group and returns to those covariates for the other group.

The conditional wage distribution is estimated by quantile regression. The conditional quantile function $Q_{\theta}(w \mid X)$ can be expressed using a linear specification for each group as follows:

$$
Q_{\theta}\left(w_{g} \mid X_{g}\right)=X_{i, g}^{T} \beta_{g, \theta} \text { for each } \theta \in(0,1)
$$

where $g=(m, f)$ represents the groups, $w$ denotes the log of hourly wage, $X_{i}$ represents the set of covariates for each individual $i$ and $\beta_{\theta}$ are the coefficient vectors that need to be estimated for the different $\theta^{\text {th }}$ quantiles.

The quantile regression coefficients can be interpreted as the returns to various characteristics at different quantiles of the conditional wage distribution. Machado and Mata (2005) estimate the counterfactual unconditional wage distribution using a simulationbased technique.

Melly (2006) proposed an alternative to the simulation-based estimator that is less computationally intensive and faster. Instead of using a random sample with replace- 
ment, Melly (2006) integrates the conditional wage distribution over the entire range of covariates to generate the marginal unconditional distribution of log wage. Then, by inverting the unconditional distribution function, the unconditional quantiles of interest can be obtained. This procedure uses all the information contained in the covariates and makes the estimator more efficient. Melly (2006) shows that this procedure is numerically identical to the Machado and Mata decomposition method when the number of simulations used in the latter goes to infinity.

We construct a counterfactual for females using the characteristics of females and the wage structure for males:

$$
C F_{\theta}^{f}=X_{f, i}^{T} \beta_{m, \theta}
$$

Using the abovementioned counterfactual, the decomposition of wage gaps of the unconditional quantile function between groups $f$ and $m$ is as follows:

$$
\Delta_{\theta}=\left(Q_{m, \theta}-C F_{\theta}^{f}\right)+\left(C F_{\theta}^{f}-Q_{f, \theta}\right)
$$

The first term on the right hand side represents the effect of characteristics (or the quantile endowment effects) and the second the effect of coefficients (or the quantile treatment effects).

\section{Data}

The Bangladesh Enterprise-based Skills Survey (ESS) for 2012 was sponsored by the World Bank and carried out by a team of the Human Development South Asia Region (Nomura et al., 2013). The World Bank, together with the government of Bangladesh and the development partners, had embarked on a comprehensive assessment of the education sector to determine whether it is responding adequately to the skill demands of firms. The survey contains only formal sector firms. This is a shortcoming of the data as the Bangladeshi economy heavily leans towards the informal sector. The ESS is a linked employer-employee survey, containing an employer survey as well as an employee survey for a random subsample of employees working in the firms surveyed 5 The survey samples 500 firms active in commerce, education, finance, manufacturing and public administration, while the employee survey samples 6,981 employees. The employer survey, that is administered to business owners or top managers, consists of a general enterprise profile, including characteristics of the firm and its managers, its recruitment and retention

\footnotetext{
${ }^{5}$ From a roster of employees provided by the firm, the random sampling is done as follows: in a small firm, every third person was interviewed; in a medium and large firm, every fifth and seventh persons were selected respectively; and if the employment size exceeds 200, every 30th person was interviewed. If a firm did not have a roster, the interviewer listed up all the employees and randomly selected the samples.
} 
practices, and the workforce training it provides. The employee survey contains detailed information on an employee's education background, work experience, and household background information. Further, the employee surveys contain modules to assess cognitive and non-cognitive skills through specific tests. The surveys were conducted between November 2012 and January 2013 through face-to-face interviews.

The Business Registry of 2009, collected by the Bangladesh Bureau of Statistics, was used as the sampling frame. The Business Registry contains 100,194 enterprises that have more than 10 employees. The sampling methodology for the ESS is stratified random sampling, with the strata being economic sector and firm size. The five economic sectors selected for sampling were commerce (wholesale/retail), education, finance, manufacturing, and public administration. These five sectors occupy 87 percent of formal sector enterprises and 91 percent of formal sector employment. ${ }^{6}$ Enterprises were categorized into three sizes: small (10-20 employees), medium (21-70 employees) and large (71 or more employees).

Cognitive skills of employees were measured through literacy and numeracy tests, both consisting of eight questions. All the questions assess primary education level of cognitive skills as many of them are taken from National Student Assessment conducted in 2011 by the Department of Primary Education. The literacy test includes reading of words and sentences, comprehension of short paragraphs, grammar, and translation from Bangla to English. The numeracy test consists of simple mathematical operations, measurement, and functional mathematics, such as cost calculation. Scores are calculated by assigning one point for each correct answer and then standardized.

Employees' personality traits were assessed by administering a battery of questions - taken from the World Bank Skills Toward Employment and Productivity (STEP) surveys - and asking them to answer on a 4-point scale ranging from "almost always", to "almost never" 7 Of these questions, 15 items measure the following five personality factors or traits, commonly identified as the Big Five: openness to experience, conscientiousness, extroversion, agreeableness, and neuroticism. The Big Five or Five-Factor Model is a broadly accepted taxonomy of personality traits (John and Srivastava, 1999). Openness to experience is the tendency to be open to new aesthetic, cultural, or intellectual experiences. Conscientiousness refers to a tendency to be organized, responsible and hard working. Extroversion relates to an outward orientation rather than being reserved. Agreeableness is related to the tendency to act in a cooperative and unselfish manner. Neuroticism (opposite of emotional stability) is the tendency to experience unpleasant emotions easily, such as anger, anxiety, depression, or vulnerability. Further,

\footnotetext{
${ }^{6}$ The selection of economic sectors was made purposively. First, the economic sectors have relatively large proportion of firms in the formal economic sector as well as large share of employees. Second, the selected economic sectors are considered to have diversity in educational and skills demand.

${ }^{7}$ These questions are available in the appendix.
} 
two questions were used to measure hostile bias which may be defined as over-attributing hostile intent to peers' behaviours, even when the actual intent is benign or ambiguous (Dodge, 2003). Finally, four questions adapted from the Melbourne Decision-Making Scale (Mann et al., 1997) were used to assess decision-making, that is, whether individuals think about the future consequences of their decisions, and if they consider multiple options when making decisions. Traits are measured by taking the average standardized score on items corresponding to each trait 8

Since we are interested in within-firm gender wage gaps, we consider firms where at least one male and one female employee have been sampled, and where we have complete information on socio-economic characteristics, cognitive skills, and personality traits for employees. This leaves us with a sample of 225 firms and 2,150 employees.9 Since wages and personality traits are measured contemporaneously in the survey, one may be concerned about reverse causality. However, as we discuss in Section 4.1, the average employee in our sample is 32 years old, falling in the working-age range, during which personality traits are most stable and any changes are not economically significant (CobbClark and Schurer, 2012 and 2013). ${ }^{10}$

\section{Results}

\subsection{Descriptive Statistics}

We begin with descriptive statistics of firm characteristics listed in Table 1. 71 percent of firms report themselves as being profitable. On average, there are 193 employees per firm of which 25 percent are females. 32 percent of the sample is made up of small firms (1020 employees), while medium (21-70 employees) and large firms (71 or more employees) account for 30 and 38 percent respectively. 61 percent of top managers in firms have a post-graduate degree. Only a paltry 4 percent of firms have females in top managerial positions. 97 percent of firms maintain either formal or informal accounts and 96 percent

\footnotetext{
${ }^{8}$ The internal reliability of each trait is determined by calculating the Cronbach alphas using the items corresponding to each trait. These are: openness to experience, 0.44 ; conscientiousness, 0.3 ; extroversion, 0.16; agreeableness, 0.3; emotional stability, 0.36; hostile bias, 0.48; decision making, 0.43. While these internal reliability coefficients are lower than the range of 0.6-0.7 that has been mostly found in the literature using longer personality inventories, note that we have three items per trait on average, and thus these values may be deemed satisfactory. Mueller and Plug (2006) discuss that reliability coefficients increase with number of items.

${ }^{9}$ Since a concern may be that that employees who respond to all questions assessing skills and traits may be different from those who do not, we checked for the existence of any selection bias with a Heckman selection model, relying on measures of survey quality (survey controllers and enumerators identifiers) as exclusion restrictions. We did not find evidence of significant selection effects in the wage regressions (results of the selection models are available from the authors upon request).

${ }^{10}$ In fact, Almlund et al. (2011) discuss that addressing the potential problem of reverse causality by using previously measured traits as predictors of later outcomes can lead to errors in variables problem if the traits evolve over time.
} 
of firms are registered with the government. These two factors reflect the high level of formality in the sampling frame of the survey, which is based on the Business Registry.

In terms of industrial sectors, the largest chunk of firms (32 percent) is engaged in manufacturing. Public administration and education make up 20-22 percent each. Finance firms constitute 19 percent while commerce represents the remaining 7 percent. Further, within the manufacturing firms, textiles and wearing apparel are the dominant activities comprising 37 percent and 27 percent respectively while food products make up 17 percent.

56 percent of firms are based in Dhaka, the capital city. Chittagong, the second largest city in Bangladesh has 10 percent of the firms, and Rajshahi and Rangpur account for 8-9 percent of firms respectively.

Moving on to employee characteristics in Table 2, out of 2,150 employees, 420 are female, thereby constituting 19.5 percent of the employee sample. Males are two years older than females (Wilcoxon rank-sum test; $p$-value $=0.00$ ) but there is no significant difference in the proportion of married males and females. Males have approximately 11 years of education, which is 1 year higher than that of females $(p-$ value $=0.09)$. Males also exhibit significantly greater tenure at the current firm $(p-$ value $=0.01)$ and experience prior to joining the current firm $(p-$ value $=0.04)$. Given these differences in endowments, a priori a higher wage for men is expected. As our data show, the average hourly wage of males is 51 taka (0.51 euros in 2014) while that of females is approximately 50 taka, with the difference being statistically significant $(p-$ value $=$ 0.00). A Kolmogorov-Smirnov test also shows that the wage distributions of males and females (as shown in Figure 1) are significantly different. Note that while this wage gap may appear small for Bangladesh where gender-based inequalities are large and fairly persistent, one should bear in mind that our sample is comprised of firms in the formal sector with at least 10 employees, and self-selection of high ability workers into the formal sector is a priori greater for women than for men (Kingdon, 1998). However, using national level household survey data for Bangladesh, Asadullah (2006) finds no evidence of significant sample selection into paid employment for both sexes ${ }^{11}$ Moreover, since the informal sector is not under consideration here, the wage gap measured here is an under-estimate of the actual income gap characterizing the labour market in Bangladesh.

Moving on to cognitive skills as measured by reading and numeracy tests, our data show that men outperform women significantly in terms of the numeracy score $(p-v a l u e$ $=0.002)$ but not in terms of reading score $(p-$ value $=0.33)$. Finally, in terms of personality traits, females report significantly higher scores on openness to experience

\footnotetext{
${ }^{11}$ Kapsos (2008) documents a gender wage gap of 21 percent using the 2007 Bangladesh Occupational Wage Survey. The nature of the sample in this survey comes closest to ours in that a third of the sample is derived from firms with more than 10 employees.
} 
$(p-$ value $=0.001)$, agreeableness $(p-$ value $=0.06)$ and neuroticism $(p-$ value $=$ $0.007)$, decision-making $(p-$ value $=0.001)$ and hostile bias $(p-$ value $=0.004)$ as compared to men.

Another factor that could explain the wage gap is differences in occupational status between males and females. While 4.6 percent of males and 2.6 percent of females are in managerial roles, approximately 19 percent of males and females are in professional positions. Further, while almost 21 percent of women are in unskilled elementary occupations, the proportion of men is 13 percent.

\subsection{The Mean Gender Wage Gap}

We first estimate OLS regressions for the pooled sample of males and females and cluster the standard errors at the firm level. The dependent variable is the log of the current hourly wage. We subsequently expand the list of explanatory variables. The first set consists of socio-economic characteristics such as marital status, years of completed education, years of prior experience and years of tenure, with a quadratic profile for the last three variables. Quadratic effects of experience and tenure are used to approximate the concave profile between these variables and wages. We also introduce a dummy variable that is equal to 1 when the worker is a woman and zero otherwise. In the second set, to measure cognitive skills, we further include standardized scores on the reading and numeracy tests. In the third set, to measure personality traits, we also include standardized values of scores on each of the Big Five traits (extroversion, agreeableness, conscientiousness, openness to experience, and emotional stability), and on hostile bias and decision-making. Next, in each of these regressions, we can pick up the role of unobserved firm heterogeneity by introducing firm dummies in the regression. Finally, dummy variables for occupational status are also added to account for the fact that wages within the same firm could differ on account of different occupations. If the female dummy variable partially picks up these occupational effects, it would lead to an over-estimated gender effect. However, a problem is that occupational assignment may itself be the result of the employer's practices and not due to differences in productivity or individual choice (Albrecht et al., 2003). Further, since we are interested in examining the effect of cognitive and non-cognitive skills on wages, we may not want to control for occupations if one believes that individuals' skills determine their occupational preferences ${ }^{12}$

Results are in Table 3. In column 1, we regress the log wage on only the female dummy and obtain a negative coefficient indicating a significant raw gender wage gap of 11.6 percent. In column 2, upon adding the socio-economic controls, the female coefficient

\footnotetext{
${ }^{12}$ Results with occupation controls are reported only for the OLS estimates. In all other estimates, we do not include occupation status for reasons outlined above. Results are available from authors from request.
} 
reduces significantly to 5.7 percent. In column 3, once the standardized scores on cognitive tests are added, the gender wage gap remains virtually unchanged at 5.9 percent. The reading score is positively linked with wages but the numeracy score is not a significant determinant. While Glewwe et al. (2013) find that reading skills are not significant when controlling for educational attainment, in our case we find reading proficiency to matter even in the presence of years of education. In column 4 , we further add the standardized scores of the personality traits, which leads to a slight drop in the female dummy to 5.5 percent. None of the personality traits are statistically significant suggesting that there is no incremental effect of these traits on mean wages. In columns 5-7, we augment each of these regressions by adding the firm dummies. The gender dummy coefficients are smaller in magnitude, as compared to columns 2-4, but are no longer significant. This indicates the existence of sorting of male and female workers across firms that pay different wages. An F-test of joint significance of the firm dummy variables shows them to be highly significant. This shows that wages are correlated with firm-specific factors, thereby making it crucial to account for firm-specific effects. In the presence of firm effects, both reading and numeracy scores have positive and significant coefficients. In column 8, we add occupation dummy variables, with the omitted category being managerial jobs. Note that the coefficient on the female dummy is reduced while still being insignificant. Cognitive test scores remain positive and significant. In results not reported in the table, we find wages on all occupation groups to be significantly lower than those of the managerial group. Across relevant columns, tests of joint significance show that cognitive skills are significant in determining mean wages while personality traits are not. In terms of other independent variables included in Table 3, we find that the education-wage relationship follows a convex profile. While this is contrary to the standard assumption of concave relationship between education and earnings, there is now ample evidence suggesting increasing returns to education across schooling levels (e.g., Kingdon and Unni, 2001; Söderbom et al., 2006). Tenure in current firm has the expected concave relationship with wages. These regressions indicate that while cognitive skills directly affect wages, personality traits do not matter for pooled mean wages across the sexes. We then proceed to checking for the existence of specific gender and distributional effects.

\subsection{Quantile Regressions}

As can be seen in Figure 2, the magnitude of the unconditional gender wage gap varies considerably throughout the wage distribution with the highest gaps being observed at the lower percentiles and the smallest (and negative) wage gaps at the highest percentiles. This phenomenon of greater wage gaps at the lower end is consistent with the "sticky floor" parabola that has been observed primarily in developing countries (e.g., Chi and Li, 
2008; Carrillo et al., 2014). We now estimate quantile regressions to determine how the magnitude of the gender wage gap changes along the wage distribution once we control for socio-economic characteristics, cognitive skills, and personality traits. By pooling the data for males and females in the quantile regression, the assumption is that the returns to endowments are the same at the various quantiles for men and women. In Table 4, we estimate pooled quantile regressions for the most inclusive specification, without firmspecific effects. The coefficient of the female dummy varies across the wage distribution with gaps being higher at the lower end. The gender wage gap is 11 percent at the $10^{\text {th }}$ percentile, and 14.1 percent at the $25^{\text {th }}$ percentile and then declining to 8.7 percent at the median. It further declines to 4.9 percent at the $75^{\text {th }}$ and becomes negligible and insignificant at the $90^{\text {th }}$ percentiles. The reading score is positive and significant at all percentiles except the $90^{\text {th }}$. Among the personality traits, openness to experience and decision-making are negatively associated with wages at the $10^{\text {th }}$ percentile.

In Table 5, we add the firm-specific effects. In order to conduct fixed effects quantile regressions, we use the method proposed by Canay (2011). This alternative approach assumes that the unobserved heterogeneity terms have a pure location shift effect on the conditional quantiles of the dependent variable. In other words, they are assumed to affect all quantiles in the same way. We notice that with the inclusion of firm-specific effects, the gender wage gap is lower at all the estimated percentiles of the wage distribution, as compared to results of Table 4. There is then evidence of sorting across firms by workers at all points of the wage distribution. The wage gap at the $90^{\text {th }}$ percentile, while reversed and now marginally in favor of women is not significant. Both reading and numeracy scores have higher correlations with wages at the lower percentiles than higher ones. Agreeableness is positively associated with wages at the $10^{\text {th }}, 25^{\text {th }}$ and $50^{\text {th }}$ percentiles, and emotional stability is positively associated with wages at the first decile. On the contrary, openness to experience is negatively associated with wages at the $10^{\text {th }}$ percentile. Conscientiousness is differentially related with wages at both ends of the conditional distribution: negatively linked with wages at the $10^{\text {th }}$ percentile, but positively related to wages at the $90^{\text {th }}$ percentile. Hence, while we do not observe significant effects of non-cognitive skills on mean wages, the observed effects are more nuanced when one looks across the conditional wage distribution.

In Table 6, we estimate the gender-specific OLS and quantile regressions with firmspecific effects. ${ }^{13}$ The reading score is positively associated with female wages at all reported percentiles but only at the $25^{\text {th }}$ and $50^{\text {th }}$ percentiles for male wages. On the other hand, the numeracy score is positively correlated with the wages of men at all points except the $90^{\text {th }}$ percentile, but is never significant for women. While in the pooled

\footnotetext{
${ }^{13}$ Results of gender-specific regressions without firm fixed effects are available from the authors upon request.
} 
quantile regressions with firm-specific effects in Table 5 we saw that the coefficients on reading and numeracy scores are positive throughout the distribution, it is now evident that these results are differentiated by gender. Considering the personality variables, we observe that conscientiousness is rewarded for women at all percentiles except the $90^{\text {th }}$. Agreeableness also has positive and mostly increasing returns for women across the conditional wage distribution. On the other hand, openness to experience has increasingly negative returns for women at the $50^{\text {th }}, 75^{\text {th }}$ and $90^{\text {th }}$ percentiles. Interestingly, we find that emotional stability is negatively related with women's wages at the median and the third quartile, although weakly. On the contrary, for men, the effects of personality traits are more sporadic and reveal no consistent pattern, indicating that these personality traits are important determinants for women's wages but not for men's wages. Nyhus and Pons (2005) using Dutch data also find that personality traits matter more for wages of females than males.

Our results of gender-specific quantile regressions provide some support about the market rewarding individuals who adhere to societal expectations about gender-appropriate traits and behaviour. For instance, agreeableness (that indicates unselfish and cooperative behaviour) is a positive quality associated with women especially in a developing country like Bangladesh where gender roles are well-defined and women may be expected to be more submissive and accommodating in nature (both at home and at the workplace), and in our sample, we find that more agreeable women are rewarded monetarily for this trait ${ }^{14}$ Further, the result that numeracy is a skill rewarded for men and literacy a skill rewarded for women also bolsters the argument of gendered cultural expectations, particularly in a gender-unequal society such as Bangladesh. Guiso et al. (2008) show that the gender gap in mathematics scores is higher in more gender-unequal societies and it becomes smaller in more gender-equal cultures. On the other hand, the reading score gap is usually in favour of women and becomes smaller in more gender-equal cultures. This could possibly lead to employers forming beliefs about comparative advantages that men and women have in numeracy and literacy skills respectively and adhering to those stereotypes.

\subsection{Decomposition Analysis}

Table 7 reports results from the mean decomposition that decomposes the average wage gap into explained and unexplained components. Panel A only includes socio-economic controls for marital status, education, tenure, prior experience, panel B also includes the standardized scores for the reading and numeracy tests, and finally in panel $\mathrm{C}$, the

\footnotetext{
${ }^{14}$ However, note that this result is in contrast to evidence from developed countries where the trait of agreeableness is generally linked to lower wages, perhaps because agreeable individuals may be "too nice", extremely cooperative, and reluctant to negotiate their wages (e.g., Nyhus and Pons, 2005; Mueller and Plug, 2006).
} 
standardized personality scores are also added. In each of the panels, we report results using the male wage structure, the female wage structure (Blinder, 1973; Oaxaca, 1973), and the Neumark pooled model. While columns 2 and 3 report the decomposition results without firm-specific effects, columns 4 and 5 include the firm-specific effects.

Without the firm-specific effects, we see that across all the three panels, using the Neumark decomposition, about half of the gap is explained by characteristics with the rest being unexplained. As we move down from panel A to panels $\mathrm{B}$ and $\mathrm{C}$, the explained component first reduces by 2 percentage points from 51.6 percent to 49.3 percent and then increases to 53.9 percent. This is in line with the coefficient of the female dummy variable marginally increasing in Table 3 as we move from including only socioeconomic characteristics in column 2 to also adding cognitive test scores in column 3. However, with the inclusion of firm-specific effects, the proportion explained increases significantly within each of the panels, as expected. Looking across panels, 74.8 percent of the wage gap is explained with only the socio-economic characteristics, and increases to 78.4 percent and reduces negligibly to 78.2 percent upon successively adding cognitive skills and personality traits respectively. Hence, in the presence of firm-specific effects, controlling for cognitive and non-cognitive skills increases the mean explained component by about 3.6 percentage points. Mirroring the OLS results from Table 3, upon comparing panels $\mathrm{B}$ and $\mathrm{C}$, we find that non-cognitive skills do not have an additional contribution over and above the cognitive skills in explaining the average gender wage gap. To the extent that the unexplained component is indicative of gender wage discrimination, controlling for previously unmeasured cognitive and non-cognitive skills gets us to a closer approximation of actual wage discrimination.

Next, we move to the quantile decompositions performed at the $10^{\text {th }}, 25^{\text {th }}, 50^{\text {th }}, 75^{\text {th }}$ and $90^{\text {th }}$ percentiles of the distribution. In Tables 8 and 9 , we report results using the male coefficients, i.e. if females were paid like males, without and with firm-specific effects respectively. Within each of the three panels, it can be seen that the raw wage gap declines as one moves from the $10^{\text {th }}$ percentile to the $90^{\text {th }}$ percentile. Further, the share of coefficients declines as one moves to the upper end of the distribution, thereby supporting the evidence of a sticky floor. This is reflected in the increasing proportion of the wage gap that can be attributed to differences in characteristics as one moves to the higher quantiles. In fact, in each of the panels of Table 9 , note that at the $75^{\text {th }}$ and $90^{\text {th }}$ percentiles, differences in characteristics between the sexes (over)explain the entire wage gap. In panel A of Table 9, the characteristics account for 28 percent of the wage gap at the $25^{\text {th }}$ percentile, and 123 percent at the $75^{\text {th }}$ percentile; in panel $\mathrm{C}$, the respective proportions are 24 and 139 percent. Besides, cognitive skills and personality traits mostly explain the gender wage gaps in the upper part of the conditional wage distribution as illustrated by the visible increase in the explained component at the $75^{\text {th }}$ 
and $90^{\text {th }}$ percentiles, as one moves from panel A to panels $\mathrm{B}$ and $\mathrm{C}$.

To sum, the decompositions highlight that, contrary to what gender-pooled regressions on mean wages predict, the effects of cognitive and non-cognitive skills are essentially gender specific, and are thereby able to explain a non-negligible proportion of the gender wage gap. Besides, looking at distributional effects, these skills and traits appear to reduce the unexplained gender gap in the upper part of the conditional wage distribution.

\subsection{Determinants of The Within-Firm Gender Wage Gap}

In this section, we look at factors on account of which firms pay males and females differently. In relation to the previous sections, the purpose of this analysis is to identify how, in particular, employers' valuation of employees' cognitive and non-cognitive skills may affect the magnitude of the within-firm gender wage gap. Indeed, to the extent that employers value certain skills more than others, and have some common beliefs or stereotypes about the ability of male and female employees in the absence of perfect information on their productivity, this could affect the premium they pay to the two groups of employees.

In order to examine this, we follow a hierarchical modelling approach (Bryk and Raudenbush, 1992), also applied in Meng (2004) and Nordman and Wolff (2009a), where wage equations for males and females are first estimated separately using a fixed effects model:

$$
\begin{gathered}
w_{i j}^{m}=\beta^{m} X_{i j}^{m}+\theta_{j}^{m}+\epsilon_{i j}^{m} \\
w_{i j}^{f}=\beta^{f} X_{i j}^{f}+\theta_{j}^{f}+\epsilon_{i j}^{f}
\end{gathered}
$$

The male and female firm fixed effects $\left(\hat{\theta}^{m}\right.$ and $\left.\hat{\theta}^{f}\right)$ retrieved from these regressions reflect a premium paid by the firm to its male and female employees respectively, since other socio-economic characteristics (marital status, years of education, prior work experience, and tenure at current firm) have already been controlled for in the above regressions.15 The difference between the male and female firm fixed effects $\left(\hat{\theta}^{m}-\hat{\theta}^{f}\right)$ is an estimate of the within-firm gender wage gap. For this exercise, from the original sample of 500 firms and 6,981 employees, we restrict the sample to those firms that have at least two male and two female employees 16 This leaves us with a sample of 165 firms and 3,231 employees (2,494 males and 737 females).

In a second step, we introduce a host of firm-level characteristics in order to explain

\footnotetext{
${ }^{15}$ Our results are robust to controlling for occupations in the first stage regressions.

${ }^{16}$ If there is only one person of each sex in a firm, the estimated firm effect would be equal to the residual estimated for this person and firm and individual residuals cannot be separated.
} 
this within-firm wage gap and use OLS regressions. The firm level characteristics we consider are: economic sector dummy variables, size of the firm, whether the firm is reported profitable, export statust7, age of the firm, proportion of female employees in the overall firm workforce, proportion of females in top managerial roles, whether the firm conducts a performance review from time to time 18 , whether the manager is female and whether the manager has completed college and higher levels of education.

Employers are also asked to state on a scale of 1-10 (with 10 being most important) how important they think it is for employees, both managers/professionals and nonprofessionals, to have each of the following skills: communication, team work, problemsolving, literacy and numeracy, customer care, responsibility, reliability and trustworthiness, creativity, and vocational job-specific skills.$^{19}$ We use the responses on each of these by computing standardized scores. In addition, employers are asked to list the top 3 cognitive and non-cognitive skills (among 14 skills in the questionnaire) they use to make decisions regarding compensation and promotions, separately for managers/professionals and non-professionals ${ }^{20}$ We then construct dummy variables for professionals and nonprofessionals respectively taking the value 1 if employers declared any non-cognitive skills to be either first or second most important, as compared to cognitive skills.

In column 1 of Table 10, we report the estimates of the within-firm gender wage gap including a set of firm characteristics and two dummy variables for whether employers value non-cognitive skills more than cognitive skills for compensation and promotion decisions for professionals and non-professionals respectively. As is evident, this variable is positive and significant for non-professionals only, implying that employers who place more weight on non-cognitive skills for this group of workers have larger gender wage gaps within their firms, that works to the disadvantage of female employees. This might be due to the fact that these employers use non-cognitive skills as signals in the absence of better information on cognitive credentials, in particular for women.

In columns 2 and 3, we introduce standardized scores of importance given by employ-

\footnotetext{
${ }^{17}$ A large literature in economic theory suggests that a firm's industrial affiliation, profitability, size and openness to international trade should all affect its compensation policy.

${ }^{18}$ Some studies indicate that firms with less information about individuals' productivity may pay one group of workers (males) more than the other group (females), the latter group conveying potentially less reliable information about its productivity (Lundberg and Startz, 1983). Hence, the gender wage gap may result from a lack of information. To control for this, it is then useful to identify firms for which individual productivity can be measured. We proxy this with a dummy taking value 1 if the firm conducts a performance review from time to time.

${ }^{19}$ Professional staff includes managers; professionals; and technical and associate professionals. Nonprofessional staff refers to clerical support workers; service workers; sales workers; skilled agricultural, forestry and fishery workers; construction, craft and related trade workers; plant and machine operators, assemblers, drivers; and those in elementary occupations.

${ }^{20}$ The set of cognitive skills are: problem solving, literacy, numeracy, ICT, general vocational jobspecific skills, advanced vocational job-specific skills and English language, while the non-cognitive skills include communication, team work, customer care, responsibility, reliability and trustworthiness, motivation and commitment, creativity, and confidence.
} 
ers to a number of cognitive and non-cognitive skills listed above, for non-professionals (column 2) and for professionals (column 3) to save on degrees of freedom. While none of the coefficients are significant for professionals, we find that firms that value problemsolving skills for non-professional workers have significantly greater gender wage gaps. This effect is robust when one considers a regression including all the regressors for professionals and non-professionals (column 4). Finally, in the most inclusive specification of column 4, valuing communication skills among non-professional workers appears to be negatively associated with the within-firm gender wage gap. Hence, in the absence of perfect observation of such skills among employees, perhaps employers make the assumption that males are better endowed than females with certain skills (such as problem solving), which would tend to increase the gender gap in the wage premium. In the same way, a supposed feminine trait like communication skills tends to decrease such a gap ${ }^{21}$

In terms of other firm characteristics, the share of females in the top management and the top manager being female is associated with smaller wage gaps within firms. This effect is robust across all specifications reported. Other variables such as education level of the manager, size of the firm, sector of operation, and proportion of females in the overall workforce are not consistently significant across columns in explaining within-firm gender wage gaps.

\section{Discussion and Conclusion}

In this paper, our objective has been to explain gender wage gaps in the formal sector of Bangladesh by including measures of cognitive skills and personality traits as additional determinants of wages. We believe it makes an important contribution especially when the existing literature on these issues is scarce for developing countries.

Our results show that, for the particular sample at hand, while cognitive skills, as measured by reading ability, are positively correlated with wages, measures of personality seem to have almost no explanatory power in determining mean wages for the pooled sample. Where the personality traits do matter, it is mostly for wages of female employees, and in certain parts of the wage distribution. Interestingly, the finding that reading and numeracy skills are positively correlated with wages across the distribution is driven by employees' sex such that reading and numeracy skills seem to confer benefits to men and women, respectively. Further, in line with OLS regressions, mean decompositions indicate that including measures of cognitive skills reduces the unexplained component by 3.6 percentage points when firm effects are also accounted for, but personality traits do not

\footnotetext{
${ }^{21}$ Alternative modeling, i.e. including cognitive and personality traits in the first step wage regressions (thus reducing the firm sample size to 108 observations due to missing observations on these traits), provides additional evidence that team-work skills tends to reduce significantly the within-firm gender wage gap.
} 
play a role. Consistent with other developing country literature, quantile decompositions indicate the presence of a sticky floor phenomenon, which is revealed by higher adjusted wage gaps at the lower end of the conditional wage distribution, with the unexplained component being larger at lower percentiles. Cognitive skills and personality traits greatly reduce the unexplained gender gap in the upper part of the conditional wage distribution.

The finding that cognitive skills and socio-economic characteristics are more important, in general, than personality traits in determining wages is also supported by the outlook of employers in our sample. In the data, employers are asked to rate how important the following criteria are on a 1-10 scale when making hiring decisions (10 being very important): academic performance, work experience, job skills and interview. 68 percent, 57 percent and 50 percent of employers rated academic performance, work experience, job skills respectively between 8 and 10. On the other hand, only 36 percent of employers considered interview to be an important selection criteria. This suggests that employers place greater consideration on observables such as academic performance and prior work experience, rather than on a face-to-face interaction during an interview, which gives them the opportunity to assess certain soft skills of the person such as their assertiveness, agreeableness, communication skills, etc. This could also point to low levels of learning and cognition in countries such as Bangladesh, which might explain why employers care more about evaluating those skills. These results are in contrast to studies based on developed countries such as the United States that find employers rank "attitude" as the most important skill among new hires (Bowles et al., 2001). Our results are however in line with other developing country studies such as Glewwe et al. (2013) that find cognitive skills to matter more than non-cognitive skills for determining wages in rural China.

Finally, we also have investigated the determinants of the within-firm gender wage gap. Share of top position females in the firm and sex of the manager all seem to be robust significant determinants of the wage gap observed inside the firm. Besides, in the absence of perfect observation of workers' productivity and skills as hypothesized above, employers appear to rely on signals to set wages. These signals may be based on skill preference and beliefs in the existence of sex-specific skills. For instance, employers seem to better remunerate those workers making proof of typical perceived sex-specific skills. How and why such stereotypes persist and cause gender inequality in labour market outcomes in Bangladesh (and more generally in developing countries) would be worth investigating further. 


\section{References:}

Ahmed, S., and Maitra, P. (2010). Gender wage discrimination in rural and urban labour markets of Bangladesh. Oxford Development Studies, 38(1), 83-112.

Ahmed, S., and Maitra, P. (2011). A Distributional Analysis of the Gender Wage Gap in Bangladesh. Monash University Working Paper.

Albrecht, J., Bjorklund, A., and Vroman, S. (2003). Is there a glass ceiling in Sweden? Journal of Labor Economics, 21(1), 145-177.

Almlund, M., Duckworth, A.L., Heckman, J.J., and Kautz, T.D. (2011). Personality Psychology and Economics in Eric A. Hanushek, Stephen Machin and Ludger Woessmann (Eds.) Handbook of Economics of Education, Vol.4, 1-181.

Appleton, S., J. Hoddinott, and P. Krishnan. (1999). The Gender Wage Gap in Three African Countries. Economic Development and Cultural Change, 47(2), 289-312.

Asadullah, M. N. (2006). Returns to Education in Bangladesh. Education Economics, 14(4), 453-468.

Babcock, L., and Laschever, S., 2003. Women Don't Ask: Negotiation and the Gender Divide. Princeton University Press, Princeton NJ

Bangladesh Bureau of Statistics (2011). Report on Labour Force Survey 2010

Blinder, A. (1973). Wage discrimination: Reduced form and structural estimates. Journal of Human Resources, 8(4), 436-455.

Borghans, L., Duckworth, A.L., Heckman, J.J., and ter Weel, B. (2008). The Economics and Psychology of Personality Traits. Journal of Human Resources, 43(4), 9721059.

Bowles, S., Gintis, H., and Osborne, M. (2001). Incentive-enhancing preferences: Personality behavior and earnings. American Economic Review Papers and Proceedings, 91, 155-158.

Braakmann, N. (2009). Psychological Traits and the Gender Gap in Full-Time Employment and Wages: Evidence from Germany. Working Paper.

Bryk, A., and Raudenbush, S. W. (1992). Hierarchical Linear Models for Social and Behavioral Research: Applications and Data Analysis Methods. Newbury Park, CA: Sage.

Canay, I. A. (2011). A simple approach to quantile regression for panel data. The Econometrics Journal, 14(3), 368-386.

Card, D., Cardoso, A.R., and Kline, P. (2013). Bargaining and the Gender Wage Gap: A Direct Assessment. IZA Discussion Paper \# 7592.

Carrillo, P., Gandelman, N., and Robano, V. (2014). Sticky floors and glass ceilings in Latin America. Journal of Economic Inequality, 12(3), 339-361. 
Carrington, William J. and Kenneth R. Troske. (1995). Gender Segregation in Small Firms. Journal of Human Resources, 30 (3), 503-533.

Chi, W., and Li, B. (2008). Glass ceiling or sticky floor? Examining the gender earnings differential across the earnings distribution in urban China, 1987-2004. Journal of Comparative Economics, 36(2), 243-263.

Cobb-Clark, D.A., and Schurer, S. (2012). The stability of Big-Five personality traits. Economics Letters, 115(1), 11-15.

Cobb-Clark, D.A., and Schurer, S. (2013). Two economists' musings on the stability of locus of control. Economic Journal, 123, F358-F400.

Cobb-Clark, D.A., and Tan, M. (2011). Noncognitive skills, occupational attainment, and relative wages. Labour Economics, 18(1), 1-13.

Croson, R., and Gneezy, U. (2009). Gender differences in preferences. Journal of Economic Literature, 47(2), 448-74.

Diaz, J.J., Arias, O., and Tudela, D.V. (2013). Does perseverance pay as much as being smart? The returns to cognitive and non-cognitive skills in urban Peru. Working paper.

Dodge, K. A. (2003). Do Social Information Processing Patterns Mediate Aggressive Behavior? In B.B. Lahey, T.E. Moffitt, and A. Caspi (Eds.) Causes of Conduct Disorder and Juvenile Delinquency. New York: Guilford Press.

Fafchamps, M., M. Söderbom, and N. Benhassine. (2006). Wage Gaps and Job Sorting in African Manufacturing. Journal of African Economies, 18(5), 824-868.

Flory, J. A., A. Leibbrandt and J. A. List (2015). Do Competitive Workplaces Deter Female Workers? A Large-Scale Natural Field Experiment on Job Entry Decisions. Review of Economic Studies, 82, 122-155.

Fortin, N. (2008). The Gender Wage Gap among Young Adults in the United States: The Importance of Money vs. People. Journal of Human Resources, 43, 886-920.

Guiso, L., Monte, F., Sapienza, P., and Zingales, L. (2008). Culture, Gender, and Math. Science, 320, 1164-1165.

Glewwe, P., Huang, Q., and Park, A. (2013). Cognitive Skills, Noncognitive Skills, and the Employment and Wages of Young Adults in Rural China. Working Paper.

Heath, R., and Mobarak, M. (2015). Manufacturing growth and the lives of Bangladeshi women. Journal of Development Economics, 115, 1-15.

Heckman, J.J., Humphries, J.E., Urzua, S., and Veramendi, G. (2011). The effects of educational choices on labor market, health, and social outcomes. Unpublished manuscript, University of Chicago, Department of Economics. 
Heckman, J.J., Stixrud, J., and Urzua, S. (2006). The effects of cognitive and noncognitive abilities on labor market outcomes and social behavior. Journal of Labor Economics, 24 (3), 411-482.

Jellal, M., Nordman, C.J., and Wolff, F-C. (2008). Evidence on the glass ceiling effect in France using matched worker-firm data. Applied Economics, 40, 3233-3250.

John, O. P., and Srivastava, S. (1999). The Big-Five trait taxonomy: History, measurement, and theoretical perspectives. In L.A. Pervin and O. P. John (Eds.), Handbook of personality: Theory and research, Vol. 2, 102-138.

Kapsos, S. (2008). Changes in Employment in Bangladesh, 2000-2005: The Impacts on Poverty and Gender Equity. Working paper series, ILO Asia-Pacific.

Khanna, S. (2012). Gender wage discrimination in India: Glass ceiling or sticky floor? CDE Working Paper \#214, Delhi School of Economics.

Kingdon, G., and Unni, J. (2001). Education and Women's Labour Market Outcomes in India. Education Economics, 9(2), 173-94.

Kingdon, G. (1998). Does the Labour Market Explain Lower Female Schooling in India? Journal of Development Studies, 35(1), 39-65.

Lindqvist, E., and Vestman, R. (2011). The Labor Market Returns to Cognitive and Noncognitive Ability: Evidence from the Swedish Enlistment. American Economic Journal: Applied Economics, 3(1), 101-128.

Lundberg ,S.J., and Startz, R. (1983). Private Discrimination and Social Intervention in Competitive Labor Markets. American Economic Review, 73, 340-347.

Machado, J., and Mata, J. (2005). Counterfactual Decomposition of Changes in Wage Distributions using Quantile Regression. Journal of Applied Econometrics, 20, 445-465.

Mann, L., Burnett, P., Radford, M., and Ford, S. (1997). The Melbourne Decision Making Questionnaire: An instrument for measuring patterns for coping with decisional conflict. Journal of Behavioral Decision Making, 10(1), 1-19.

Melly, B. (2006). Estimation of counterfactual distributions using quantile regression. Review of Labor Economics, 68, 543-572.

Meng, X. (2004). Gender earnings gap: the role of firm specific effects. Labour Economics, 11, 555-573.

Mueller, G., and Plug, E. (2006). Estimating the effects of personality on male and female earnings. Industrial and Labor Relations Review, 60 (1), 3-22.

Neumark, D. (1988). Employers Discriminatory Behaviour and the Estimation of Wage Discrimination. Journal of Human Resources, 23(3), 279-295.

Niederle, M. and Vesterlund, L. (2007). Do Women Shy Away from Competition? Do Men Compete to Much? Quarterly Journal of Economics, 122(3), 1067-1101. 
Nomura, S., S.Y. Hong, C.J. Nordman, L.R.Sarr, L. and A.Y. Vawda (2013). An assessment of skills in the formal sector labor market in Bangladesh : a technical report on the enterprise-based skills survey 2012. South Asia Human Development Sector report No. 64. Washington DC; The World Bank.

Nordman, C.J., and Roubaud, F. (2009). Reassessing the gender wage gap in Madagascar: does labour force attachment really matter? Economic Development and Cultural Change, 57(4), 785-808.

Nordman, C. J., A.S. Robilliard, and F. Roubaud. (2011). Gender and ethnic earnings gaps in seven West African cities. Labour Economics, 18, Supplement 1, pp. S132-S145.

Nordman, C.J., and Wolff F-C. (2009a). Is There a Glass Ceiling in Morocco? Evidence from Matched Worker-Firm Data. Journal of African Economies, 18(4), 592-633.

Nordman, C.J., and Wolff F-C. (2009b). Islands Through the Glass Ceiling? Evidence of Gender Wage Gaps in Madagascar and Mauritius. In Labor Markets and Economic Development, Kanbur R. and Svejnar J. (eds), Chapter 25, pp. 521-544, Routledge Studies in Development Economics, Routledge.

Nyhus, E., and Pons, E. (2005). The effects of personality on earnings. Journal of Economic Psychology, 26(3), 363-384.

Oaxaca, R. (1973). Male-female wage differentials in urban labor markets. International Economic Review, 14(3), 693-709.

Pham, T., and Reilly, B. (2007). The gender pay gap in Vietnam: 1993-2002: A quantile regression approach. Journal of Asian Economics, 18(5), 775-808.

Semykina, A., and Linz, S.J. (2007). Gender differences in personality and earnings: evidence from Russia. Journal of Economic Psychology, 28, 387-410.

Söderbom, M., F. Teal, A. Wambugu and G. Kahyarara (2006). The Dynamics of Returns to Education in Kenyan and Tanzanian Manufacturing. Oxford Bulletin of Economics and Statistics, 68(3), 261-88. 
Table 1: Descriptive Statistics of Firm Characteristics

\begin{tabular}{lcc}
\hline \hline Variable & Mean & SD \\
\hline Making profit & 0.71 & 0.45 \\
Number of employees & 192.8 & 810.8 \\
Share of female employees & 0.25 & 0.17 \\
Top manager: female & 0.04 & 0.19 \\
Top manager: post-graduate level education & 0.61 & 0.49 \\
Small (10-20 employees) & 0.324 & 0.47 \\
Medium (21-70 employees) & 0.298 & 0.46 \\
Large (71+ employees) & 0.378 & 0.49 \\
Maintain accounts (either formal or informal) & 0.97 & 0.16 \\
Registered with government & 0.96 & 0.21 \\
Industrial sector: & & \\
Commerce & 0.067 & 0.25 \\
Education & 0.227 & 0.42 \\
Finance & 0.191 & 0.39 \\
Manufacturing & 0.316 & 0.46 \\
Public Admn & 0.2 & 0.4 \\
Location: & & \\
Rajshahi & 0.093 & 0.29 \\
Khulna & 0.071 & 0.26 \\
Dhaka & 0.56 & 0.50 \\
Chittagong & 0.102 & 0.30 \\
Barisal & 0.049 & 0.22 \\
Sylhet & 0.044 & 0.21 \\
Rangpur & 0.08 & 0.27 \\
\hline Number of firms & 225 & \\
\hline \hline
\end{tabular}

Source: Authors' calculations using the Bangladesh Enterprise Skills Survey, 2012. 
Table 2: Descriptive Statistics of Employee Characteristics

\begin{tabular}{|c|c|c|c|}
\hline Variable & All & Males & Females \\
\hline Females & $\begin{array}{c}0.195 \\
(0.39)\end{array}$ & & \\
\hline Hourly wage (in taka) & $\begin{array}{c}50.91 \\
(54.75)\end{array}$ & $\begin{array}{c}50.92 \\
(45.76)\end{array}$ & $\begin{array}{c}50.87 \\
(82.06)\end{array}$ \\
\hline Ln(hourly wage) & $\begin{array}{c}3.69 \\
(0.63)\end{array}$ & $\begin{array}{c}3.72 \\
(0.61)\end{array}$ & $\begin{array}{c}3.60 \\
(0.69)\end{array}$ \\
\hline Age & $\begin{array}{l}32.26 \\
(8.49)\end{array}$ & $\begin{array}{l}32.62 \\
(8.51)\end{array}$ & $\begin{array}{l}30.81 \\
(8.27)\end{array}$ \\
\hline Married & $\begin{array}{c}0.80 \\
(0.40)\end{array}$ & $\begin{array}{c}0.80 \\
(0.40)\end{array}$ & $\begin{array}{c}0.80 \\
(0.40)\end{array}$ \\
\hline Years of education & $\begin{array}{c}10.57 \\
(4.92)\end{array}$ & $\begin{array}{l}10.69 \\
(4.85)\end{array}$ & $\begin{array}{l}10.10 \\
(5.21)\end{array}$ \\
\hline Tenure in current firm & $\begin{array}{c}5.94 \\
(6.08)\end{array}$ & $\begin{array}{c}6.09 \\
(6.17)\end{array}$ & $\begin{array}{c}5.3 \\
(5.66)\end{array}$ \\
\hline Years of prior experience & $\begin{array}{c}1.92 \\
(2.93)\end{array}$ & $\begin{array}{c}1.98 \\
(3.01)\end{array}$ & $\begin{array}{c}1.65 \\
(2.58)\end{array}$ \\
\hline Cognitive Skills: & & & \\
\hline$\overline{\text { Reading test score }}$ & $\begin{array}{c}4.96 \\
(2.54)\end{array}$ & $\begin{array}{c}5.01 \\
(2.49)\end{array}$ & $\begin{array}{c}4.77 \\
(2.75)\end{array}$ \\
\hline Numeracy test score & $\begin{array}{c}5.76 \\
(1.99)\end{array}$ & $\begin{array}{c}5.84 \\
(1.94)\end{array}$ & $\begin{array}{c}5.44 \\
(2.17)\end{array}$ \\
\hline Personality Traits: & & & \\
\hline$\overline{\text { Openness to experience }}$ & $\begin{array}{c}2.60 \\
(0.59)\end{array}$ & $\begin{array}{c}2.59 \\
(0.59)\end{array}$ & $\begin{array}{c}2.68 \\
(0.59)\end{array}$ \\
\hline Conscientiousness & $\begin{array}{c}2.86 \\
(0.58)\end{array}$ & $\begin{array}{c}2.87 \\
(0.57)\end{array}$ & $\begin{array}{c}2.83 \\
(0.58)\end{array}$ \\
\hline Extroversion & $\begin{array}{c}2.32 \\
(0.49)\end{array}$ & $\begin{array}{c}2.32 \\
(0.50)\end{array}$ & $\begin{array}{c}2.33 \\
(0.49)\end{array}$ \\
\hline Agreeableness & $\begin{array}{c}2.57 \\
(0.58)\end{array}$ & $\begin{array}{c}2.56 \\
(0.57)\end{array}$ & $\begin{array}{c}2.62 \\
(0.60)\end{array}$ \\
\hline Emotional Stability & $\begin{array}{c}2.71 \\
(0.56)\end{array}$ & $\begin{array}{c}2.73 \\
(0.56)\end{array}$ & $\begin{array}{c}2.65 \\
(0.56)\end{array}$ \\
\hline Hostile Bias & $\begin{array}{c}2.38 \\
(0.73)\end{array}$ & $\begin{array}{c}2.36 \\
(0.72)\end{array}$ & $\begin{array}{c}2.47 \\
(0.74)\end{array}$ \\
\hline Decision-making & $\begin{array}{c}2.56 \\
(0.55)\end{array}$ & $\begin{array}{c}2.54 \\
(0.55)\end{array}$ & $\begin{array}{c}2.64 \\
(0.54)\end{array}$ \\
\hline
\end{tabular}

Source: Authors' calculations using the Bangladesh Enterprise

Skills Survey, 2012. Standard deviation reported in parentheses.

The maximum score for the reading and numeracy tests is 8 . The

maximum score for the personality traits is 4 . 


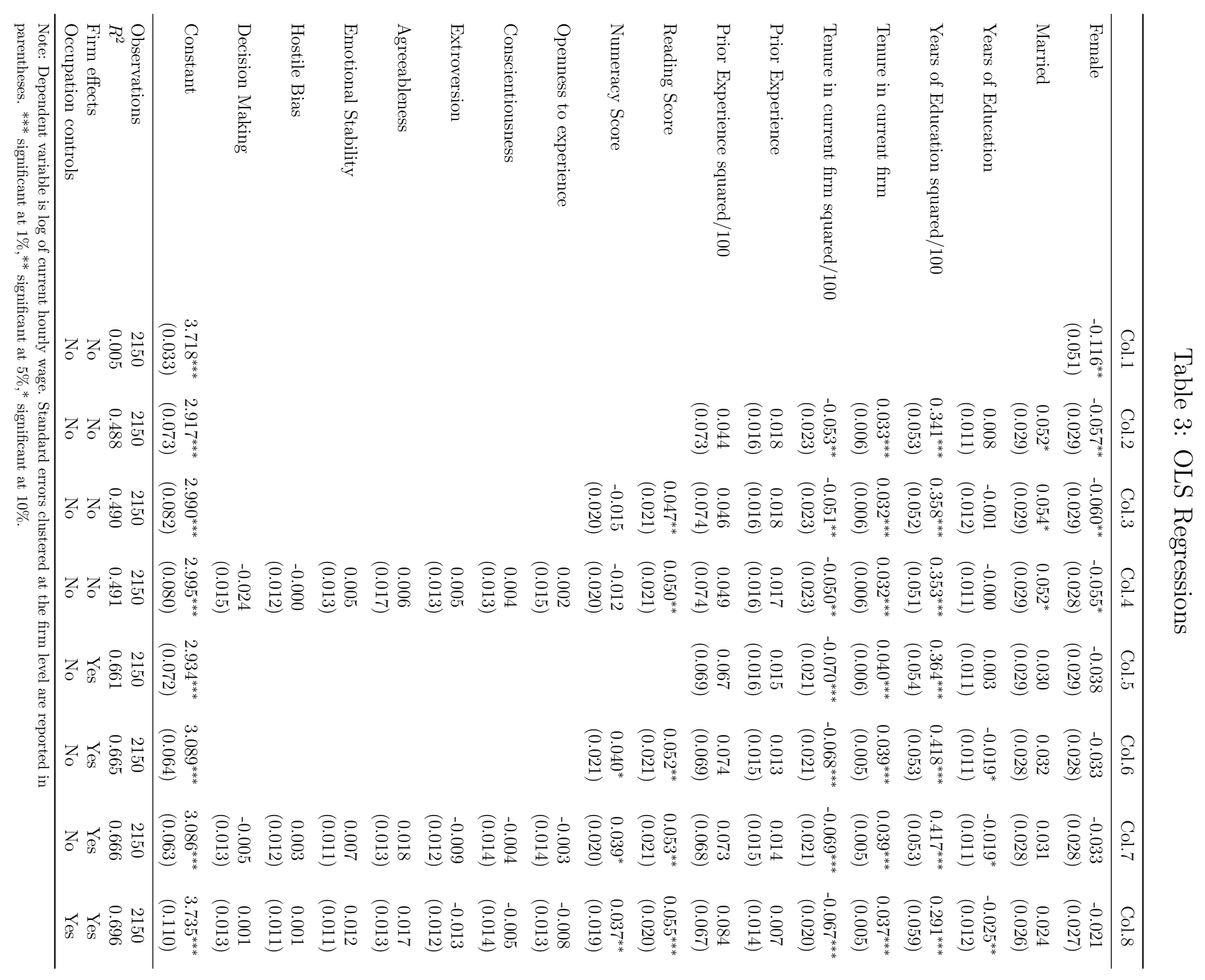


Table 4: Quantile Regressions

\begin{tabular}{|c|c|c|c|c|c|}
\hline & Q10 & Q25 & Q50 & Q75 & Q90 \\
\hline Female & $\begin{array}{c}-0.111^{* * *} \\
(0.038)\end{array}$ & $\begin{array}{c}-0.141^{* * *} \\
(0.040)\end{array}$ & $\begin{array}{c}-0.087^{* * *} \\
(0.027)\end{array}$ & $\begin{array}{l}-0.049 \\
(0.031)\end{array}$ & $\begin{array}{c}-0.007 \\
(0.048)\end{array}$ \\
\hline Married & $\begin{array}{c}0.109^{* * *} \\
(0.037)\end{array}$ & $\begin{array}{c}0.099^{* * *} \\
(0.035)\end{array}$ & $\begin{array}{l}0.057^{* *} \\
(0.025)\end{array}$ & $\begin{array}{c}0.049 \\
(0.037)\end{array}$ & $\begin{array}{c}0.028 \\
(0.041)\end{array}$ \\
\hline Years of Education & $\begin{array}{l}-0.017 \\
(0.015)\end{array}$ & $\begin{array}{l}-0.010 \\
(0.013)\end{array}$ & $\begin{array}{l}-0.011 \\
(0.009)\end{array}$ & $\begin{array}{l}-0.008 \\
(0.010)\end{array}$ & $\begin{array}{c}0.007 \\
(0.015)\end{array}$ \\
\hline Years of Education squared/100 & $\begin{array}{c}0.390^{* * *} \\
(0.054)\end{array}$ & $\begin{array}{c}0.361^{* * *} \\
(0.052)\end{array}$ & $\begin{array}{c}0.380^{* * *} \\
(0.038)\end{array}$ & $\begin{array}{c}0.397^{* * *} \\
(0.050)\end{array}$ & $\begin{array}{c}0.418^{* * *} \\
(0.078)\end{array}$ \\
\hline Tenure in current firm & $\begin{array}{c}0.011 \\
(0.008)\end{array}$ & $\begin{array}{c}0.030^{* * *} \\
(0.007)\end{array}$ & $\begin{array}{c}0.032^{* * *} \\
(0.007)\end{array}$ & $\begin{array}{c}0.036^{* * *} \\
(0.007)\end{array}$ & $\begin{array}{c}0.041^{* * *} \\
(0.008)\end{array}$ \\
\hline Tenure in current firm squared/100 & $\begin{array}{l}-0.005 \\
(0.028)\end{array}$ & $\begin{array}{c}-0.063^{* *} \\
(0.029)\end{array}$ & $\begin{array}{c}-0.053^{*} \\
(0.027)\end{array}$ & $\begin{array}{l}-0.044 \\
(0.031)\end{array}$ & $\begin{array}{c}-0.069^{* *} \\
(0.028)\end{array}$ \\
\hline Prior Experience & $\begin{array}{c}-0.001 \\
(0.013)\end{array}$ & $\begin{array}{c}0.009 \\
(0.014)\end{array}$ & $\begin{array}{l}0.030^{* *} \\
(0.013)\end{array}$ & $\begin{array}{c}0.028^{*} \\
(0.014)\end{array}$ & $\begin{array}{c}0.014 \\
(0.018)\end{array}$ \\
\hline Prior Experience squared/100 & $\begin{array}{c}0.061 \\
(0.048)\end{array}$ & $\begin{array}{c}0.033 \\
(0.063)\end{array}$ & $\begin{array}{l}-0.013 \\
(0.071)\end{array}$ & $\begin{array}{c}0.007 \\
(0.083)\end{array}$ & $\begin{array}{c}0.151 \\
(0.101)\end{array}$ \\
\hline Reading Score & $\begin{array}{l}0.060^{* *} \\
(0.030)\end{array}$ & $\begin{array}{c}0.055^{* * *} \\
(0.020)\end{array}$ & $\begin{array}{c}0.056^{* * *} \\
(0.018)\end{array}$ & $\begin{array}{c}0.067^{* * *} \\
(0.020)\end{array}$ & $\begin{array}{c}0.030 \\
(0.025)\end{array}$ \\
\hline Numeracy Score & $\begin{array}{c}0.014 \\
(0.020)\end{array}$ & $\begin{array}{c}0.000 \\
(0.015)\end{array}$ & $\begin{array}{l}-0.010 \\
(0.011)\end{array}$ & $\begin{array}{l}-0.028 \\
(0.019)\end{array}$ & $\begin{array}{l}-0.038 \\
(0.026)\end{array}$ \\
\hline Openness to experience & $\begin{array}{c}-0.034^{*} \\
(0.019)\end{array}$ & $\begin{array}{l}-0.007 \\
(0.013)\end{array}$ & $\begin{array}{c}0.003 \\
(0.011)\end{array}$ & $\begin{array}{c}0.011 \\
(0.017)\end{array}$ & $\begin{array}{c}0.005 \\
(0.017)\end{array}$ \\
\hline Conscientiousness & $\begin{array}{l}-0.001 \\
(0.018)\end{array}$ & $\begin{array}{l}-0.014 \\
(0.013)\end{array}$ & $\begin{array}{c}0.003 \\
(0.012)\end{array}$ & $\begin{array}{c}0.016 \\
(0.014)\end{array}$ & $\begin{array}{c}0.021 \\
(0.019)\end{array}$ \\
\hline Extroversion & $\begin{array}{l}-0.005 \\
(0.015)\end{array}$ & $\begin{array}{c}0.016 \\
(0.012)\end{array}$ & $\begin{array}{c}0.006 \\
(0.009)\end{array}$ & $\begin{array}{c}0.017 \\
(0.013)\end{array}$ & $\begin{array}{c}0.000 \\
(0.014)\end{array}$ \\
\hline Agreeableness & $\begin{array}{c}0.014 \\
(0.021)\end{array}$ & $\begin{array}{c}0.019 \\
(0.014)\end{array}$ & $\begin{array}{c}0.004 \\
(0.011)\end{array}$ & $\begin{array}{c}-0.011 \\
(0.015)\end{array}$ & $\begin{array}{c}-0.000 \\
(0.015)\end{array}$ \\
\hline Emotional Stability & $\begin{array}{c}0.023 \\
(0.020)\end{array}$ & $\begin{array}{c}0.013 \\
(0.012)\end{array}$ & $\begin{array}{l}-0.006 \\
(0.012)\end{array}$ & $\begin{array}{l}-0.006 \\
(0.015)\end{array}$ & $\begin{array}{c}0.006 \\
(0.016)\end{array}$ \\
\hline Hostile Bias & $\begin{array}{l}-0.001 \\
(0.017)\end{array}$ & $\begin{array}{c}0.003 \\
(0.013)\end{array}$ & $\begin{array}{c}0.003 \\
(0.009)\end{array}$ & $\begin{array}{c}0.006 \\
(0.015)\end{array}$ & $\begin{array}{c}0.002 \\
(0.019)\end{array}$ \\
\hline Decision Making & $\begin{array}{l}-0.031^{*} \\
(0.017)\end{array}$ & $\begin{array}{l}-0.014 \\
(0.015)\end{array}$ & $\begin{array}{l}-0.017 \\
(0.012)\end{array}$ & $\begin{array}{l}-0.012 \\
(0.016)\end{array}$ & $\begin{array}{c}-0.026 \\
(0.017)\end{array}$ \\
\hline Constant & $\begin{array}{c}2.720^{* * *} \\
(0.096)\end{array}$ & $\begin{array}{c}2.834^{* * *} \\
(0.085)\end{array}$ & $\begin{array}{c}3.041^{* * *} \\
(0.062)\end{array}$ & $\begin{array}{c}3.209^{* * *} \\
(0.062)\end{array}$ & $\begin{array}{c}3.294^{* * *} \\
(0.081)\end{array}$ \\
\hline Observations & 2150 & 2150 & 2150 & 2150 & 2150 \\
\hline
\end{tabular}


Table 5: Quantile Regressions (with firm specific effects)

\begin{tabular}{|c|c|c|c|c|c|}
\hline & Q10 & Q25 & Q50 & Q75 & Q90 \\
\hline Female & $\begin{array}{c}-0.075^{* * *} \\
(0.027)\end{array}$ & $\begin{array}{c}-0.073^{* * *} \\
(0.023)\end{array}$ & $\begin{array}{c}-0.045^{* *} \\
(0.019)\end{array}$ & $\begin{array}{c}-0.042^{*} \\
(0.023)\end{array}$ & $\begin{array}{c}0.009 \\
(0.036)\end{array}$ \\
\hline Married & $\begin{array}{c}0.047^{*} \\
(0.027)\end{array}$ & $\begin{array}{c}0.025 \\
(0.021)\end{array}$ & $\begin{array}{c}0.044^{* * *} \\
(0.016)\end{array}$ & $\begin{array}{l}0.046^{* *} \\
(0.023)\end{array}$ & $\begin{array}{c}0.035 \\
(0.035)\end{array}$ \\
\hline Years of Education & $\begin{array}{c}-0.034^{* * *} \\
(0.011)\end{array}$ & $\begin{array}{c}-0.037^{* * *} \\
(0.007)\end{array}$ & $\begin{array}{c}-0.022^{* * *} \\
(0.005)\end{array}$ & $\begin{array}{l}-0.007 \\
(0.008)\end{array}$ & $\begin{array}{l}-0.011 \\
(0.009)\end{array}$ \\
\hline Years of Education squared/100 & $\begin{array}{c}0.458^{* * *} \\
(0.050)\end{array}$ & $\begin{array}{c}0.489^{* * *} \\
(0.030)\end{array}$ & $\begin{array}{c}0.428^{* * *} \\
(0.023)\end{array}$ & $\begin{array}{c}0.381^{* * *} \\
(0.038)\end{array}$ & $\begin{array}{c}0.423^{* * *} \\
(0.052)\end{array}$ \\
\hline Tenure in current firm & $\begin{array}{c}0.037^{* * *} \\
(0.008)\end{array}$ & $\begin{array}{c}0.041^{* * *} \\
(0.003)\end{array}$ & $\begin{array}{c}0.041^{* * *} \\
(0.005)\end{array}$ & $\begin{array}{c}0.037^{* * *} \\
(0.005)\end{array}$ & $\begin{array}{c}0.037^{* * *} \\
(0.006)\end{array}$ \\
\hline Tenure in current firm squared/100 & $\begin{array}{c}-0.074^{* *} \\
(0.031)\end{array}$ & $\begin{array}{c}-0.077^{* * *} \\
(0.012)\end{array}$ & $\begin{array}{c}-0.075^{* * *} \\
(0.019)\end{array}$ & $\begin{array}{c}-0.052^{* *} \\
(0.021)\end{array}$ & $\begin{array}{c}-0.044^{* *} \\
(0.019)\end{array}$ \\
\hline Prior Experience & $\begin{array}{c}0.011 \\
(0.016)\end{array}$ & $\begin{array}{c}0.011 \\
(0.010)\end{array}$ & $\begin{array}{c}0.008 \\
(0.008)\end{array}$ & $\begin{array}{c}0.016 \\
(0.012)\end{array}$ & $\begin{array}{c}0.021 \\
(0.015)\end{array}$ \\
\hline Prior Experience squared/100 & $\begin{array}{c}0.029 \\
(0.080)\end{array}$ & $\begin{array}{c}0.055 \\
(0.048)\end{array}$ & $\begin{array}{c}0.072 \\
(0.050)\end{array}$ & $\begin{array}{c}0.080 \\
(0.065)\end{array}$ & $\begin{array}{c}0.112 \\
(0.078)\end{array}$ \\
\hline Reading Score & $\begin{array}{c}0.070^{* * *} \\
(0.018)\end{array}$ & $\begin{array}{c}0.071^{* * *} \\
(0.015)\end{array}$ & $\begin{array}{c}0.055^{* * *} \\
(0.014)\end{array}$ & $\begin{array}{c}0.036^{* * *} \\
(0.013)\end{array}$ & $\begin{array}{c}0.033^{*} \\
(0.017)\end{array}$ \\
\hline Numeracy Score & $\begin{array}{c}0.046^{* * *} \\
(0.017)\end{array}$ & $\begin{array}{c}0.032^{* * *} \\
(0.011)\end{array}$ & $\begin{array}{c}0.029^{* * *} \\
(0.009)\end{array}$ & $\begin{array}{l}0.027^{* *} \\
(0.012)\end{array}$ & $\begin{array}{c}0.034^{* *} \\
(0.017)\end{array}$ \\
\hline Openness to experience & $\begin{array}{l}-0.024^{*} \\
(0.014)\end{array}$ & $\begin{array}{l}-0.010 \\
(0.011)\end{array}$ & $\begin{array}{l}-0.001 \\
(0.009)\end{array}$ & $\begin{array}{c}0.012 \\
(0.011)\end{array}$ & $\begin{array}{c}0.002 \\
(0.014)\end{array}$ \\
\hline Conscientiousness & $\begin{array}{c}-0.033^{* *} \\
(0.016)\end{array}$ & $\begin{array}{c}-0.012 \\
(0.010)\end{array}$ & $\begin{array}{c}-0.001 \\
(0.008)\end{array}$ & $\begin{array}{l}-0.003 \\
(0.010)\end{array}$ & $\begin{array}{c}0.025^{*} \\
(0.015)\end{array}$ \\
\hline Extroversion & $\begin{array}{l}-0.009 \\
(0.010)\end{array}$ & $\begin{array}{l}-0.011 \\
(0.008)\end{array}$ & $\begin{array}{l}-0.009 \\
(0.009)\end{array}$ & $\begin{array}{c}0.002 \\
(0.010)\end{array}$ & $\begin{array}{l}-0.006 \\
(0.013)\end{array}$ \\
\hline Agreeableness & $\begin{array}{c}0.029^{*} \\
(0.017)\end{array}$ & $\begin{array}{l}0.023^{* *} \\
(0.011)\end{array}$ & $\begin{array}{l}0.020^{* *} \\
(0.008)\end{array}$ & $\begin{array}{c}0.018 \\
(0.014)\end{array}$ & $\begin{array}{c}0.005 \\
(0.015)\end{array}$ \\
\hline Emotional Stability & $\begin{array}{c}0.025^{*} \\
(0.014)\end{array}$ & $\begin{array}{l}-0.000 \\
(0.010)\end{array}$ & $\begin{array}{c}0.011 \\
(0.010)\end{array}$ & $\begin{array}{c}0.010 \\
(0.012)\end{array}$ & $\begin{array}{l}-0.006 \\
(0.014)\end{array}$ \\
\hline Hostile Bias & $\begin{array}{c}0.002 \\
(0.015)\end{array}$ & $\begin{array}{c}0.002 \\
(0.011)\end{array}$ & $\begin{array}{c}0.009 \\
(0.010)\end{array}$ & $\begin{array}{l}-0.001 \\
(0.009)\end{array}$ & $\begin{array}{c}0.004 \\
(0.016)\end{array}$ \\
\hline Decision Making & $\begin{array}{l}-0.024 \\
(0.015)\end{array}$ & $\begin{array}{l}-0.008 \\
(0.011)\end{array}$ & $\begin{array}{c}-0.007 \\
(0.009)\end{array}$ & $\begin{array}{l}-0.003 \\
(0.011)\end{array}$ & $\begin{array}{l}-0.002 \\
(0.015)\end{array}$ \\
\hline Constant & $\begin{array}{c}2.841^{* * *} \\
(0.065)\end{array}$ & $\begin{array}{c}3.004^{* * *} \\
(0.044)\end{array}$ & $\begin{array}{c}3.080^{* * *} \\
(0.033)\end{array}$ & $\begin{array}{c}3.168^{* * *} \\
(0.051)\end{array}$ & $\begin{array}{c}3.351^{* * *} \\
(0.056)\end{array}$ \\
\hline Observations & 2150 & 2150 & 2150 & 2150 & 2150 \\
\hline
\end{tabular}




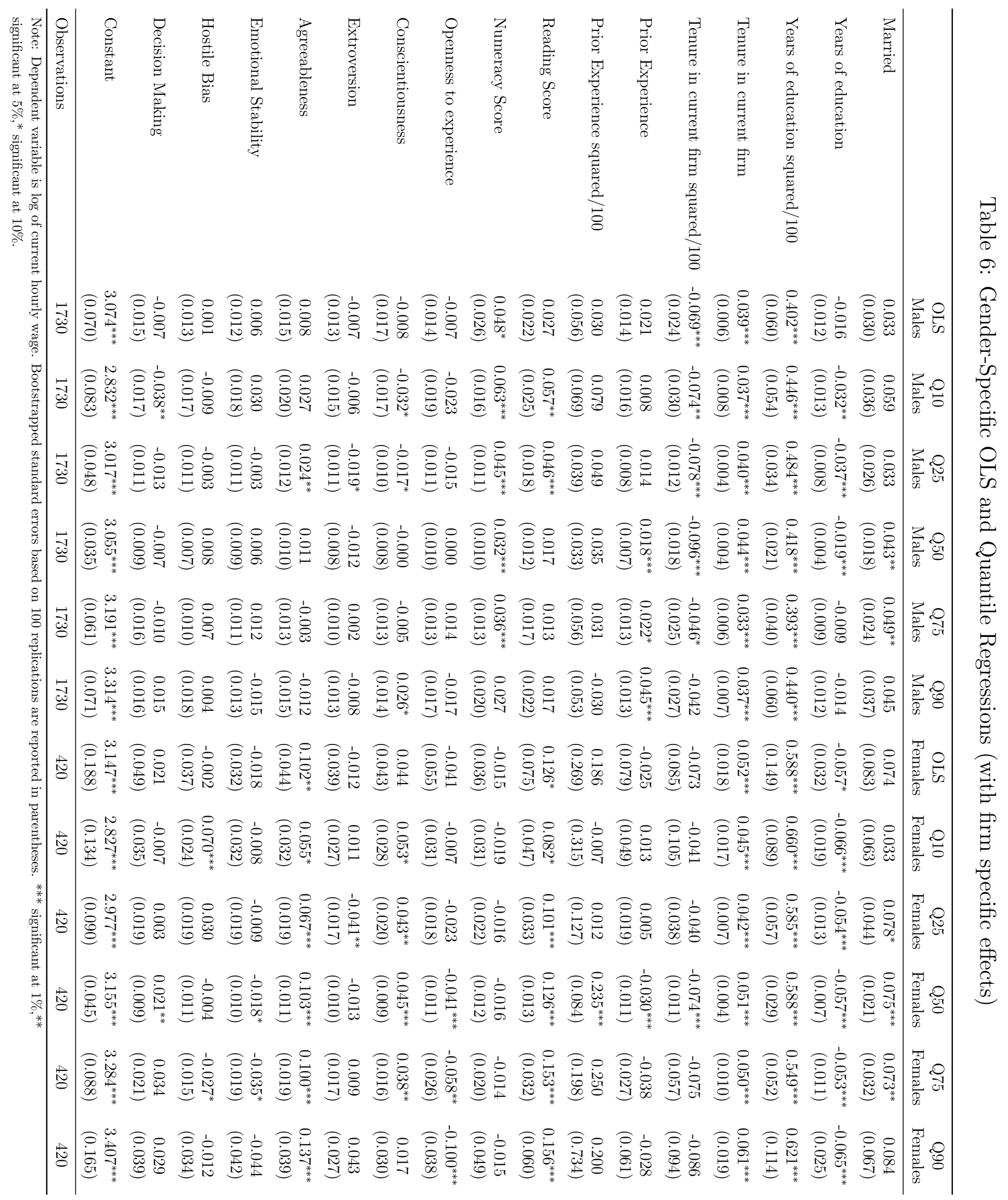


Table 7: Mean Wage Decomposition

\begin{tabular}{|c|c|c|c|c|c|}
\hline & Col. 1 & $\begin{array}{l}\text { Col. } 2 \\
\text { Without firm fixed effects }\end{array}$ & Col. 3 & $\begin{array}{c}\text { Col. } 4 \\
\text { With firm fixed effects }\end{array}$ & Col. 5 \\
\hline $\begin{array}{l}\text { Panel A: } \\
\text { Only socio-economic characteristics }\end{array}$ & $\begin{array}{c}\text { Total } \\
\text { difference }\end{array}$ & $\begin{array}{l}\text { Difference in } \\
\text { endowments }\end{array}$ & $\begin{array}{c}\text { Difference in } \\
\text { coefficients }\end{array}$ & $\begin{array}{l}\text { Difference in } \\
\text { endowments }\end{array}$ & $\begin{array}{l}\text { Difference in } \\
\text { coefficients }\end{array}$ \\
\hline Male non-discriminatory structure & 0.116 & 0.067 & 0.049 & 0.015 & 0.101 \\
\hline Female non-discriminatory structure & 0.116 & 0.057 & 0.059 & 0.076 & 0.04 \\
\hline Pooled (Neumark) non-discriminatory structure & 0.116 & 0.060 & 0.056 & 0.087 & 0.029 \\
\hline$\%$ of wage gap (Neumark) & 100 & 51.6 & 48.4 & 74.8 & 25.2 \\
\hline \multicolumn{6}{|l|}{$\begin{array}{l}\text { Panel B: } \\
\text { Adding cognitive skills }\end{array}$} \\
\hline Male non-discriminatory structure & 0.116 & 0.056 & 0.06 & 0.034 & 0.082 \\
\hline Female non-discriminatory structure & 0.116 & 0.055 & 0.061 & 0.08 & 0.036 \\
\hline Pooled (Neumark) non-discriminatory structure & 0.116 & 0.057 & 0.059 & 0.091 & 0.025 \\
\hline$\%$ of wage gap (Neumark) & 100 & 49.3 & 50.7 & 78.4 & 21.6 \\
\hline \multicolumn{6}{|l|}{$\begin{array}{l}\text { Panel C: } \\
\text { Adding personality scores }\end{array}$} \\
\hline Male non-discriminatory structure & 0.116 & 0.06 & 0.056 & 0.038 & 0.078 \\
\hline Female non-discriminatory structure & 0.116 & 0.061 & 0.055 & 0.08 & 0.036 \\
\hline Pooled (Neumark) non-discriminatory structure & 0.116 & 0.062 & 0.053 & 0.091 & 0.025 \\
\hline$\%$ of wage gap (Neumark) & 100 & 53.9 & 46.1 & 78.2 & 21.8 \\
\hline
\end{tabular}

Note: Panel A includes education, tenure, experience and the squared terms. Panel B further adds standardized scores for cognitive skills. In Panel C, standardized personality scores are also included. 
Table 8: Quantile Decompositions of Log Wage Gaps

\begin{tabular}{|c|c|c|c|}
\hline Percentile & $\begin{array}{c}\text { Col.1 } \\
\text { Difference }\end{array}$ & $\begin{array}{c}\text { Col.2 } \\
\text { Characteristics } \\
\end{array}$ & $\begin{array}{c}\text { Col.3 } \\
\text { Coefficients }\end{array}$ \\
\hline \multicolumn{4}{|c|}{ Panel A: Only socio-economic characteristics } \\
\hline 10 & $\begin{array}{c}0.182^{* * *} \\
(0.018)\end{array}$ & $\begin{array}{c}0.036 \\
(0.035)\end{array}$ & $\begin{array}{c}0.146^{* * *} \\
(0.036)\end{array}$ \\
\hline 25 & $\begin{array}{c}0.171^{* * *} \\
(0.013)\end{array}$ & $\begin{array}{c}0.045 \\
(0.029)\end{array}$ & $\begin{array}{c}0.126^{* * *} \\
(0.033)\end{array}$ \\
\hline 50 & $\begin{array}{c}0.123^{* * *} \\
(0.014)\end{array}$ & $\begin{array}{l}0.055^{*} \\
(0.027)\end{array}$ & $\begin{array}{c}0.068^{* * *} \\
(0.033)\end{array}$ \\
\hline 75 & $\begin{array}{c}0.088^{* * *} \\
(0.018)\end{array}$ & $\begin{array}{l}0.085^{*} \\
(0.039)\end{array}$ & $\begin{array}{c}0.003 \\
(0.047)\end{array}$ \\
\hline 90 & $\begin{array}{l}0.054^{* *} \\
(0.025)\end{array}$ & $\begin{array}{l}0.13^{*} \\
(0.065)\end{array}$ & $\begin{array}{l}-0.077 \\
(0.071)\end{array}$ \\
\hline \multicolumn{4}{|c|}{ Panel B: Adding cognitive skills } \\
\hline 10 & $\begin{array}{c}0.194 \\
(0.184)\end{array}$ & $\begin{array}{c}0.022 \\
(0.069)\end{array}$ & $\begin{array}{c}0.172^{* * *} \\
(0.063)\end{array}$ \\
\hline 25 & $\begin{array}{c}0.173^{* *} \\
(0.08)\end{array}$ & $\begin{array}{c}0.037 \\
(0.032)\end{array}$ & $\begin{array}{c}0.136^{* * *} \\
(0.031)\end{array}$ \\
\hline 50 & $\begin{array}{c}0.118^{* * *} \\
(0.022)\end{array}$ & $\begin{array}{l}0.055 \\
(0.03)\end{array}$ & $\begin{array}{l}0.064^{*} \\
(0.035)\end{array}$ \\
\hline 75 & $\begin{array}{l}0.082^{* *} \\
(0.042)\end{array}$ & $\begin{array}{c}0.077 \\
(0.044)\end{array}$ & $\begin{array}{c}0.005 \\
(0.049)\end{array}$ \\
\hline 90 & $\begin{array}{c}0.063 \\
(0.132)\end{array}$ & $\begin{array}{c}0.114 \\
(0.071)\end{array}$ & $\begin{array}{l}-0.051 \\
(0.078)\end{array}$ \\
\hline \multicolumn{4}{|c|}{ Panel C: Adding personality scores } \\
\hline 10 & $\begin{array}{c}0.187^{* * *} \\
(0.018)\end{array}$ & $\begin{array}{c}0.019 \\
(0.038)\end{array}$ & $\begin{array}{c}0.168^{* * *} \\
(0.034)\end{array}$ \\
\hline 25 & $\begin{array}{c}0.167^{* * *} \\
(0.014)\end{array}$ & $\begin{array}{c}0.042 \\
(0.029)\end{array}$ & $\begin{array}{c}0.125^{* * *} \\
(0.029)\end{array}$ \\
\hline 50 & $\begin{array}{c}0.111^{* * *} \\
(0.016)\end{array}$ & $\begin{array}{l}0.052 \\
(0.03)\end{array}$ & $\begin{array}{l}0.059^{*} \\
(0.036)\end{array}$ \\
\hline 75 & $\begin{array}{c}0.091^{* * *} \\
(0.021)\end{array}$ & $\begin{array}{l}0.084^{*} \\
(0.037)\end{array}$ & $\begin{array}{l}0.007 \\
(0.044)\end{array}$ \\
\hline 90 & $\begin{array}{c}0.063^{* * *} \\
(0.027)\end{array}$ & $\begin{array}{l}0.107^{*} \\
(0.055)\end{array}$ & $\begin{array}{l}-0.044 \\
(0.059)\end{array}$ \\
\hline
\end{tabular}

Note: Bootstrapped standard errors based on 150 replications reported in parentheses. ${ }^{* * *}$ significant at $1 \%,{ }^{* *}$ significant at $5 \%,{ }^{*}$ significant at $10 \%$. Panel A includes education, tenure, experience and the squared terms. Panel B further adds standardized scores for cognitive skills. In Panel C, standardized personality scores are also included. 
Table 9: Quantile Decompositions of Log Wage Gaps (with firm specific effects)

\begin{tabular}{|c|c|c|c|}
\hline Percentile & $\begin{array}{c}\text { Col.1 } \\
\text { Difference }\end{array}$ & $\begin{array}{c}\text { Col.2 } \\
\text { Characteristics }\end{array}$ & $\begin{array}{c}\text { Col.3 } \\
\text { Coefficients }\end{array}$ \\
\hline \multicolumn{4}{|c|}{ Panel A: Only socio-economic characteristics } \\
\hline 10 & $\begin{array}{c}0.163^{* * *} \\
(0.014)\end{array}$ & $\begin{array}{c}0.028 \\
(0.026)\end{array}$ & $\begin{array}{c}0.134^{* * *} \\
(0.028)\end{array}$ \\
\hline 25 & $\begin{array}{c}0.141^{* * *} \\
(0.013)\end{array}$ & $\begin{array}{c}0.039 \\
(0.023)\end{array}$ & $\begin{array}{c}0.102^{* * *} \\
(0.025)\end{array}$ \\
\hline 50 & $\begin{array}{c}0.109^{* * *} \\
(0.015)\end{array}$ & $\begin{array}{l}0.058 \\
(0.028)\end{array}$ & $\begin{array}{l}0.051 \\
(0.034)\end{array}$ \\
\hline 75 & $\begin{array}{c}0.076^{* * *} \\
(0.019)\end{array}$ & $\begin{array}{l}0.094^{* *} \\
(0.039)\end{array}$ & $\begin{array}{l}-0.018 \\
(0.041)\end{array}$ \\
\hline 90 & $\begin{array}{c}0.071^{* * *} \\
(0.02)\end{array}$ & $\begin{array}{c}0.135^{* * *} \\
(0.052)\end{array}$ & $\begin{array}{l}-0.064 \\
(0.051)\end{array}$ \\
\hline \multicolumn{4}{|c|}{ Panel B: Adding cognitive skills } \\
\hline 10 & $\begin{array}{c}0.165^{* * *} \\
(0.015)\end{array}$ & $\begin{array}{c}0.011 \\
(0.029)\end{array}$ & $\begin{array}{c}0.154^{* * *} \\
(0.028)\end{array}$ \\
\hline 25 & $\begin{array}{c}0.147^{* * *} \\
(0.015)\end{array}$ & $\begin{array}{c}0.039 \\
(0.026)\end{array}$ & $\begin{array}{c}0.107^{* * *} \\
(0.029)\end{array}$ \\
\hline 50 & $\begin{array}{c}0.096^{* * *} \\
(0.016)\end{array}$ & $\begin{array}{l}0.051 \\
(0.03)\end{array}$ & $\begin{array}{c}0.045 \\
(0.039)\end{array}$ \\
\hline 75 & $\begin{array}{l}0.06^{* * *} \\
(0.019)\end{array}$ & $\begin{array}{l}0.083^{* *} \\
(0.035)\end{array}$ & $\begin{array}{l}-0.023 \\
(0.045)\end{array}$ \\
\hline 90 & $\begin{array}{c}0.072^{* * *} \\
(0.021)\end{array}$ & $\begin{array}{l}0.129^{* *} \\
(0.049)\end{array}$ & $\begin{array}{l}-0.057 \\
(0.054)\end{array}$ \\
\hline \multicolumn{4}{|c|}{ Panel C: Adding personality scores } \\
\hline 10 & $\begin{array}{c}0.171^{* * *} \\
(0.013)\end{array}$ & $\begin{array}{c}0.009 \\
(0.029)\end{array}$ & $\begin{array}{c}0.162^{* * *} \\
(0.027)\end{array}$ \\
\hline 25 & $\begin{array}{c}0.146^{* * *} \\
(0.012)\end{array}$ & $\begin{array}{c}0.035 \\
(0.027)\end{array}$ & $\begin{array}{c}0.111^{* * *} \\
(0.028)\end{array}$ \\
\hline 50 & $\begin{array}{c}0.092^{* * *} \\
(0.016)\end{array}$ & $\begin{array}{c}0.049 \\
(0.028)\end{array}$ & $\begin{array}{c}0.043 \\
(0.037)\end{array}$ \\
\hline 75 & $\begin{array}{c}0.064^{* * *} \\
(0.021)\end{array}$ & $\begin{array}{l}0.089^{* *} \\
(0.032)\end{array}$ & $\begin{array}{r}-0.025 \\
(0.04)\end{array}$ \\
\hline 90 & $\begin{array}{c}0.064^{* * *} \\
(0.022)\end{array}$ & $\begin{array}{l}0.126^{* *} \\
(0.047)\end{array}$ & $\begin{array}{l}-0.061 \\
(0.059)\end{array}$ \\
\hline
\end{tabular}

Note: Bootstrapped standard errors based on 150 replications reported in parentheses. ${ }^{* * *}$ significant at $1 \%,{ }^{* *}$ significant at $5 \%,{ }^{*}$ significant at $10 \%$. Panel A includes education, tenure, experience and the squared terms. Panel B further adds standardized scores for cognitive skills. In Panel C, standardized personality scores are also included. 
Table 10: Within-Firm Gender Wage Gap

\begin{tabular}{|c|c|c|c|c|}
\hline & Col.1 & Col.2 & Col.3 & Col.4 \\
\hline Education & $\begin{array}{c}-0.199^{* *} \\
(0.092)\end{array}$ & $\begin{array}{c}-0.189^{*} \\
(0.106)\end{array}$ & $\begin{array}{c}-0.189^{*} \\
(0.110)\end{array}$ & $\begin{array}{l}-0.176 \\
(0.116)\end{array}$ \\
\hline Finance & $\begin{array}{c}-0.167^{* *} \\
(0.084)\end{array}$ & $\begin{array}{c}-0.186^{* *} \\
(0.093)\end{array}$ & $\begin{array}{l}-0.160 \\
(0.097)\end{array}$ & $\begin{array}{l}-0.161 \\
(0.102)\end{array}$ \\
\hline Manufacturing & $\begin{array}{l}-0.207 \\
(0.125)\end{array}$ & $\begin{array}{c}-0.280^{* *} \\
(0.138)\end{array}$ & $\begin{array}{c}-0.180 \\
(0.142)\end{array}$ & $\begin{array}{l}-0.243 \\
(0.151)\end{array}$ \\
\hline Public Admn & $\begin{array}{l}-0.104 \\
(0.103)\end{array}$ & $\begin{array}{l}-0.110 \\
(0.118)\end{array}$ & $\begin{array}{l}-0.086 \\
(0.119)\end{array}$ & $\begin{array}{l}-0.092 \\
(0.125)\end{array}$ \\
\hline 21-70 employees & $\begin{array}{l}-0.108 \\
(0.070)\end{array}$ & $\begin{array}{l}-0.077 \\
(0.064)\end{array}$ & $\begin{array}{l}-0.094 \\
(0.072)\end{array}$ & $\begin{array}{l}-0.082 \\
(0.071)\end{array}$ \\
\hline 71 or more employees & $\begin{array}{l}-0.131^{*} \\
(0.067)\end{array}$ & $\begin{array}{l}-0.076 \\
(0.065)\end{array}$ & $\begin{array}{l}-0.110 \\
(0.073)\end{array}$ & $\begin{array}{l}-0.071 \\
(0.069)\end{array}$ \\
\hline Age of firm & $\begin{array}{c}0.001 \\
(0.001)\end{array}$ & $\begin{array}{c}0.001 \\
(0.001)\end{array}$ & $\begin{array}{c}0.001 \\
(0.001)\end{array}$ & $\begin{array}{c}0.001 \\
(0.001)\end{array}$ \\
\hline$\%$ of females & $\begin{array}{c}0.310^{*} \\
(0.182)\end{array}$ & $\begin{array}{c}0.290 \\
(0.199)\end{array}$ & $\begin{array}{c}0.311 \\
(0.205)\end{array}$ & $\begin{array}{c}0.240 \\
(0.211)\end{array}$ \\
\hline$\%$ of top mgmt females & $\begin{array}{c}-0.486^{* * *} \\
(0.170)\end{array}$ & $\begin{array}{c}-0.422^{* *} \\
(0.188)\end{array}$ & $\begin{array}{c}-0.414^{* *} \\
(0.183)\end{array}$ & $\begin{array}{l}-0.385^{*} \\
(0.198)\end{array}$ \\
\hline Formal performance review & $\begin{array}{c}0.001 \\
(0.045)\end{array}$ & $\begin{array}{c}0.005 \\
(0.049)\end{array}$ & $\begin{array}{c}0.009 \\
(0.047)\end{array}$ & $\begin{array}{c}0.020 \\
(0.050)\end{array}$ \\
\hline Firm is profitable & $\begin{array}{c}0.048 \\
(0.055)\end{array}$ & $\begin{array}{c}0.035 \\
(0.056)\end{array}$ & $\begin{array}{c}0.049 \\
(0.054)\end{array}$ & $\begin{array}{c}0.034 \\
(0.057)\end{array}$ \\
\hline Firm exports & $\begin{array}{c}0.021 \\
(0.079)\end{array}$ & $\begin{array}{c}0.053 \\
(0.084)\end{array}$ & $\begin{array}{c}0.043 \\
(0.081)\end{array}$ & $\begin{array}{c}0.053 \\
(0.085)\end{array}$ \\
\hline Female manager & $\begin{array}{c}-0.187^{* *} \\
(0.089)\end{array}$ & $\begin{array}{c}-0.192^{* *} \\
(0.094)\end{array}$ & $\begin{array}{c}-0.202^{* *} \\
(0.091)\end{array}$ & $\begin{array}{c}-0.190^{*} \\
(0.097)\end{array}$ \\
\hline Manager college educated & $\begin{array}{l}-0.153 \\
(0.106)\end{array}$ & $\begin{array}{l}-0.184^{*} \\
(0.103)\end{array}$ & $\begin{array}{c}-0.164 \\
(0.103)\end{array}$ & $\begin{array}{l}-0.180^{*} \\
(0.096)\end{array}$ \\
\hline Value non-cognitive skills for non-professionals & $\begin{array}{l}0.131^{* *} \\
(0.057)\end{array}$ & & & \\
\hline Value non-cognitive skills for professionals & $\begin{array}{c}0.012 \\
(0.047)\end{array}$ & & & \\
\hline$\frac{\text { Importance given for non-professionals: }}{\text { Communication skills }}$ & & $\begin{array}{l}-0.044 \\
(0.038)\end{array}$ & & $\begin{array}{l}-0.102^{*} \\
(0.057)\end{array}$ \\
\hline Team work skills & & $\begin{array}{l}-0.029 \\
(0.033)\end{array}$ & & $\begin{array}{l}-0.015 \\
(0.035)\end{array}$ \\
\hline Problem solving skills & & $\begin{array}{l}0.086^{* *} \\
(0.039)\end{array}$ & & $\begin{array}{l}0.099^{* *} \\
(0.049)\end{array}$ \\
\hline Literacy skills & & $\begin{array}{l}-0.029 \\
(0.045)\end{array}$ & & $\begin{array}{l}-0.040 \\
(0.055)\end{array}$ \\
\hline Numeracy skills & & $\begin{array}{l}-0.011 \\
(0.035)\end{array}$ & & $\begin{array}{l}-0.008 \\
(0.043)\end{array}$ \\
\hline Customer care skills & & $\begin{array}{l}-0.001 \\
(0.035)\end{array}$ & & $\begin{array}{l}-0.006 \\
(0.040)\end{array}$ \\
\hline Responsibility & & $\begin{array}{c}0.018 \\
(0.037)\end{array}$ & & $\begin{array}{c}0.019 \\
(0.047)\end{array}$ \\
\hline Creativity & & $\begin{array}{l}-0.015 \\
(0.031)\end{array}$ & & $\begin{array}{l}-0.038 \\
(0.042)\end{array}$ \\
\hline Vocational job-specific skills & & $\begin{array}{l}-0.015 \\
(0.035)\end{array}$ & & $\begin{array}{l}-0.012 \\
(0.059)\end{array}$ \\
\hline \multicolumn{5}{|l|}{ Importance given for professionals: } \\
\hline Communication skills & & & $\begin{array}{c}0.002 \\
(0.031)\end{array}$ & $\begin{array}{c}0.061 \\
(0.047)\end{array}$ \\
\hline Team work skills & & & $\begin{array}{c}0.002 \\
(0.034)\end{array}$ & $\begin{array}{c}0.020 \\
(0.034)\end{array}$ \\
\hline Problem solving skills & & & $\begin{array}{l}-0.018 \\
(0.034)\end{array}$ & $\begin{array}{l}-0.055 \\
(0.040)\end{array}$ \\
\hline Literacy skills & & & $\begin{array}{l}-0.009 \\
(0.033)\end{array}$ & $\begin{array}{c}0.007 \\
(0.041)\end{array}$ \\
\hline Numeracy skills & & & $\begin{array}{l}-0.004 \\
(0.033)\end{array}$ & $\begin{array}{c}0.001 \\
(0.042)\end{array}$ \\
\hline Customer care skills & & & $\begin{array}{l}-0.021 \\
(0.038)\end{array}$ & $\begin{array}{l}-0.005 \\
(0.039)\end{array}$ \\
\hline Responsibility & & & $\begin{array}{c}0.022 \\
(0.033)\end{array}$ & $\begin{array}{l}-0.006 \\
(0.044)\end{array}$ \\
\hline Creativity & & & $\begin{array}{c}0.045 \\
(0.034)\end{array}$ & $\begin{array}{c}0.053 \\
(0.044)\end{array}$ \\
\hline Vocational job-specific skills & & & $\begin{array}{c}-0.031 \\
(0.030) \\
\end{array}$ & $\begin{array}{l}-0.005 \\
(0.053) \\
\end{array}$ \\
\hline Observations & 164 & 164 & 164 & 164 \\
\hline$R^{2}$ & 0.189 & 0.218 & 0.189 & 0.256 \\
\hline
\end{tabular}


Figure 1: Hourly Wage Distributions by Gender

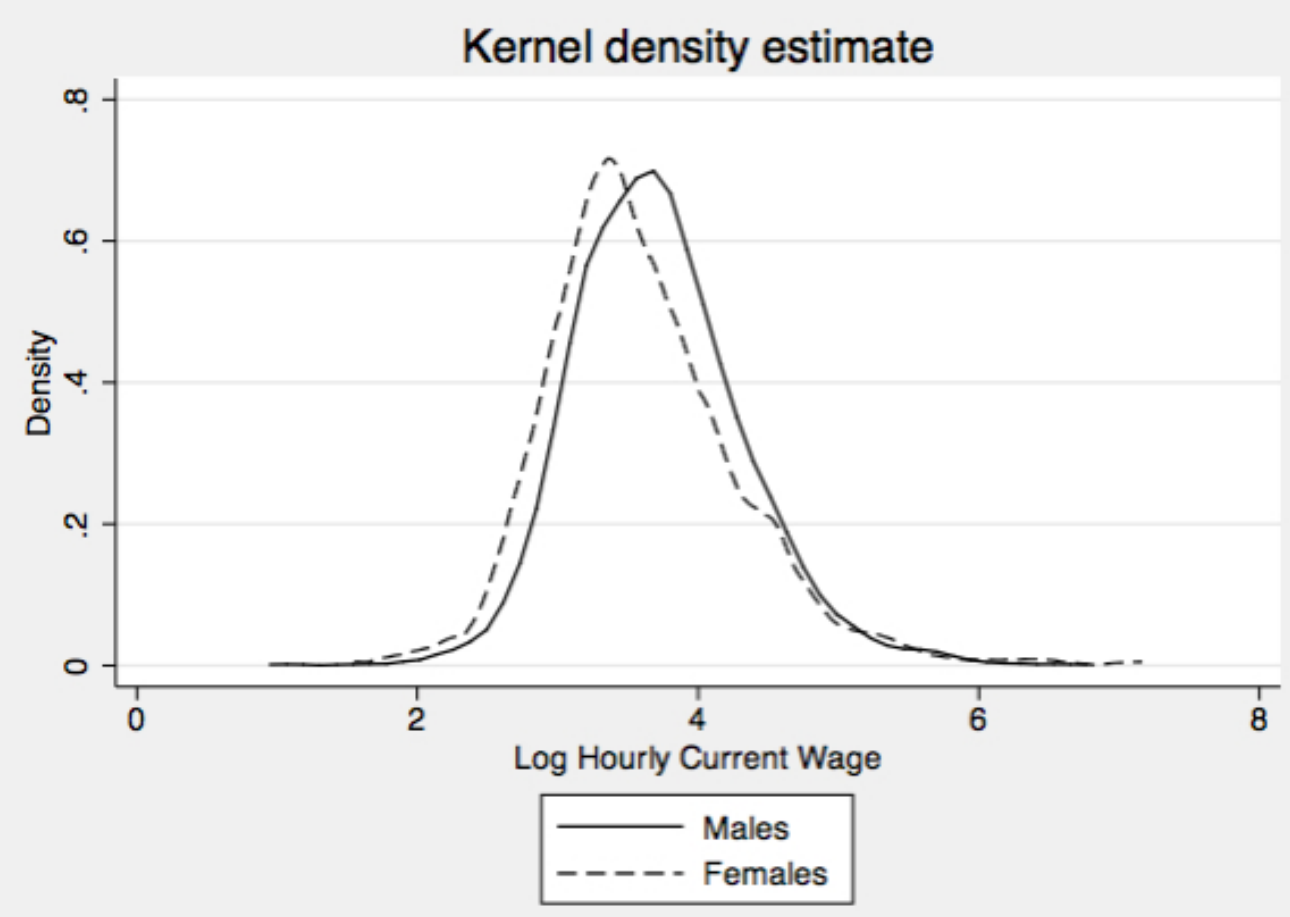

Figure 2: Gender Wage Gap Distribution

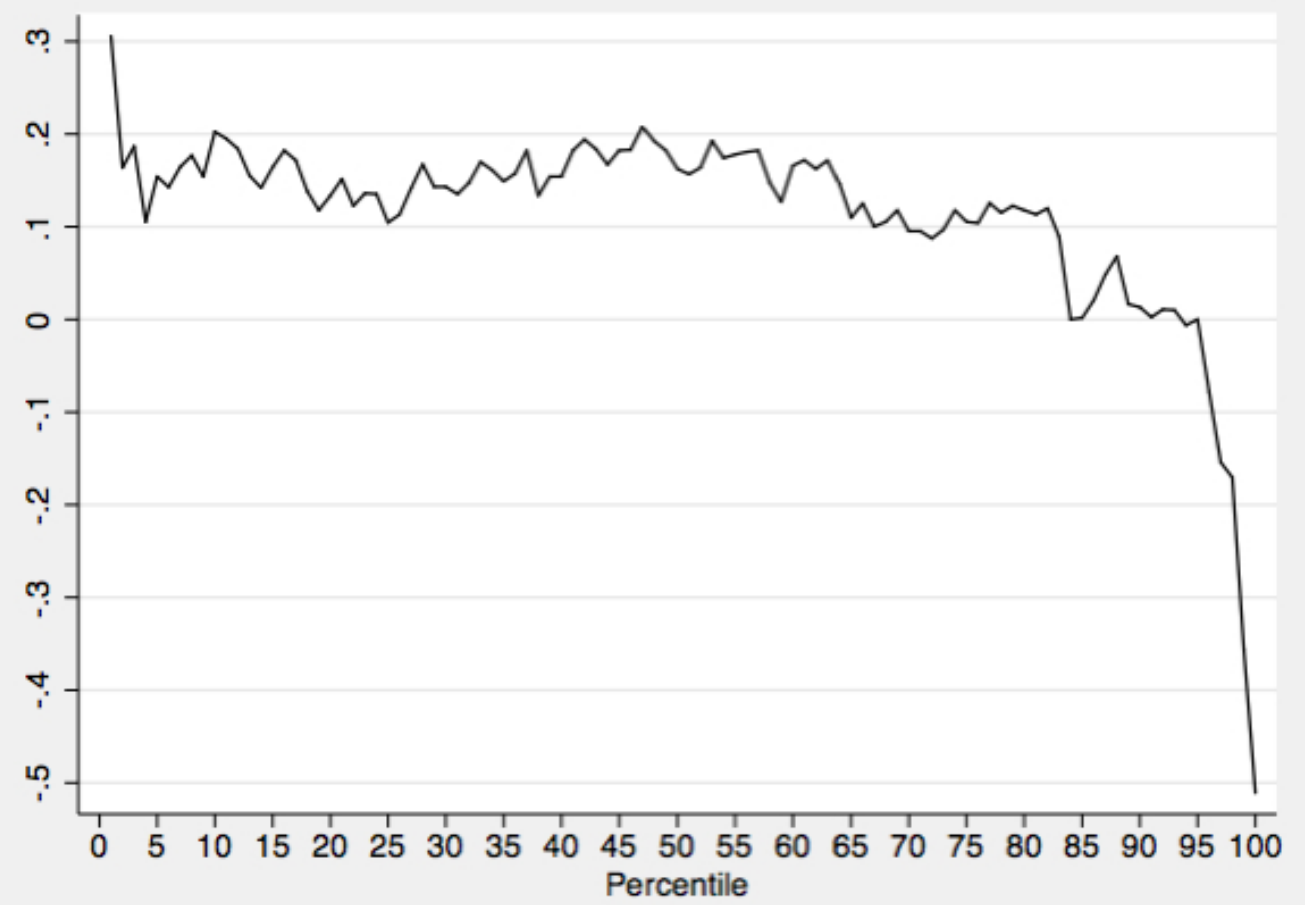




\section{A Personality Questionnaire}

How do you see yourself?

Response scale: Almost always; Most of the time; Some of the time; Almost never

\section{Agreeableness:}

Are you very polite to other people?

Are you generous to other people with your time or money?

Do you forgive other people easily?

\section{Conscientiousness:}

When doing a task, are you very careful?

Do you work very well and quickly?

Do you prefer relaxation more than hard work?

\section{Neuroticism:}

Are you relaxed during stressful situations?

Do you tend to worry?

Do you get nervous easily?

\section{Extroversion:}

Are you talkative?

Are you outgoing and sociable, for example, do you make friends very easily?

Do you like to keep your opinions to yourself?

\section{Openness:}

Do you come up with ideas other people haven't thought of before?

Are you very interested in learning new things?

Do you enjoy beautiful things, like nature, art and music?

\section{Hostile Attribution Bias:}

Do people take advantage of you?

Are people mean/not nice to you?

\section{Decision-making:}

Do you think about how the things you do will affect you in the future?

Do you think carefully before you make an important decision?

Do you ask for help when you don't understand something?

Do you think about how the things you do will affect others? 